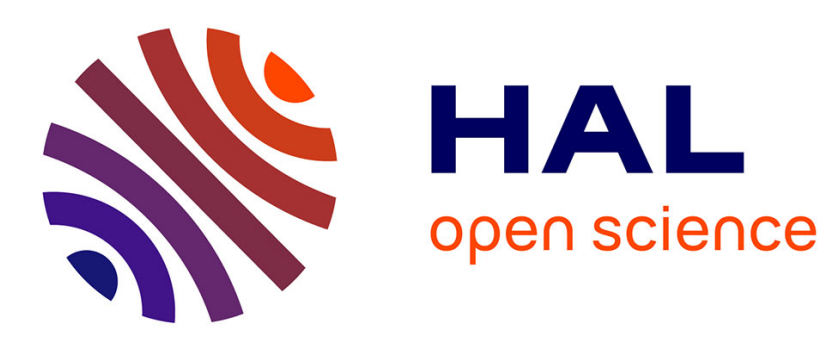

\title{
Careers Patterns in Greek Academia: Social Capital and Intelligent Careers, but for Whom?
}

\author{
Nikos Bozionelos
}

\section{To cite this version:}

Nikos Bozionelos. Careers Patterns in Greek Academia: Social Capital and Intelligent Careers, but for Whom?. Career Development International, 2014, 19 (3), pp.264-294. 10.1108/CDI-01-2014-0011. hal-01016605

\section{HAL Id: hal-01016605 \\ https://hal-audencia.archives-ouvertes.fr/hal-01016605}

Submitted on 22 Jul 2014

HAL is a multi-disciplinary open access archive for the deposit and dissemination of scientific research documents, whether they are published or not. The documents may come from teaching and research institutions in France or abroad, or from public or private research centers.
L'archive ouverte pluridisciplinaire HAL, est destinée au dépôt et à la diffusion de documents scientifiques de niveau recherche, publiés ou non, émanant des établissements d'enseignement et de recherche français ou étrangers, des laboratoires publics ou privés. 


\title{
Careers Patterns in Greek Academia: Social Capital and Intelligent Careers, but for Whom?
}

Nikos Bozonielos, Audencia PRES LUNAM, Nantes, France

\begin{abstract}
Purpose: To develop an account for careers within the Greek academic system. Historical, cultural and geographical features of the country have created a rather unique context that has apparently shaped the way academic careers evolve.

Design/methodology/approach: The primary methods of data collection were retrospective participant observation and discussions in interview form with individuals who have had various types of experience with the Greek Higher Education system.

Findings: The major factor that shapes careers in Greek academia is social capital or Knowwhom that operates within a broader cultural environment where institutional collectivism is extremely low, the in-group - out-group distinction is a major element, and political ideology plays an important role in everyday affairs. As a result academic careers in Greece are almost exclusively determined by membership, a priory or earned, to an "in-group" that is linked via blood, family friendship, business and political party ties. This "in-group" uses its social capital to control academic careers across all stages for the benefit of its members and at the expense of "outsiders".

Research limitations/implications: There are method limitations, but relevant concerns were largely alleviated by precautionary measures and the way data were utilized. Ethnography may be the most appropriate method to disentangle the way networks and social capital impact careers.

Practical implications: Achieving substantive change, such as increasing meritocracy, within a particular sector may not be possible without consideration of the broader cultural context that encapsulates it.
\end{abstract}


Originality/value: The study is amongst the very first to unveil the "dark side" of social capital, and show how social capital may benefit the interests of in-groups at the expense of the collective. Keywords: Academia, Greece, careers, social capital, dark side, intelligent careers, knowwhom, career stage, national culture, in-group, politics, political parties, nepotism, cronyism; corruption; organized crime

\section{Careers Patterns in Greek Academia: Social Capital and Intelligent Careers, but for Whom?}

The research examines careers in the Greek academic system to illustrate the mechanisms via which cultural and environmental characteristics have led to the particular patterns that careers follow within that system. The investigation employs the construct of social capital (Bourdieu, 1980, 1986), which signifies the resources an individual has at his/her disposal by means of his/her relationship ties with other individuals or groups, and the notion of intelligent careers (Arthur, Claman \& DeFillippi, 1995), which poses that maximization of career prospects is achieved by means of cultivating three competency domains: relationship ties, aspirations, and knowledge, skills and credentials.

The contribution of the research lies on two aspects: (1) It provides an illustration of how careers are embedded within social and cultural systems, which frame career trajectories and essentially cage career actors by means of seriously restricting their latitude of action: as to be seen, there are only certain patterns of conduct for entry and progression within the Greek academic system, and these are mostly determined by a priori membership or not into a particular "in-group". Deviations from such behavioural patterns for "out-group" members either preclude entry or seriously curtail probabilities of progress or even survival once into the system. (2) it illustrates the negative effects social capital can have for the collective (i.e., in this case the academia of a whole country, with probably repercussions on the country itself) when a particular "in-group" utilizes it exclusively to advance its own interests; and implies that the cultural context in which careers are embedded may influence whether social capital plays a benign or a malignant role within the collective. Social capital (Bourdieu, 1980) has been a popular concept in business and social science research over the 
past twenty years, but it has been mostly considered in terms of its benefits for individuals, firms and the collective. The present work exposes the potentially negative consequences or "dark side" of social capital that has been mostly neglected so far.

\section{Setting the Stage}

Greece is a country with very long history, whose origins are traced well beyond one millennium BC. In addition, Greece has been granted the status of a country that offered lights to the rise of intellect, and is viewed as the cradle of modern western civilization (e.g., Barzum, 2000; Finley, 1985; Norton \& Company, 2010).

What is known as modern Greece was founded nearly 200 years ago (in 1830 AD). It is important to note that the modern Greek State has been in existence over a longer amount of time than some countries that have played and play a dominant role in the political, social and economic affairs of the modern world; including Germany and Italy (e.g., see United Nations, 2013). However, and despite having a relatively long history as an independent country-state within modern Europe, Greece has failed at national level to make an impact in modern academic affairs, even if one controls for its size and other key factors, such as turmoil during its modern history (this observation excludes individual Greek academics and researchers who, predominantly from positions in foreign countries, have left substantial individual marks in their disciplines).

In reaching that conclusion one simply has to compare Greece with countries of shorter histories as independent states and of comparable populations that have also gone through similar or even worse difficulties in their modern histories. Such countries, for example, include Czech Republic and Slovakia (being a unified single country, Czechoslovakia, from 1918 until 1993). These countries have shorter lifetimes than Greece and had also gone, like Greece, through devastation in the second World War (e.g., see Wilkinson \& Hughes, 2003). In addition, unlike Greece, they had been under communist regime for nearly forty years in their recent history (1945-1992), a regime that has been 
arguably connected to scientific isolation and economic stagnation (e.g., see Sakwa, 1999).

Nevertheless, the academic communities of Czech Republic and Slovakia have achieved the entry of a number of their academic journals into Thomson Reuters indexing [formerly Institute of Scientific Information (Testa, 2012)]. Indexing by Thomson Reuters is arguably the strongest and most reliable indication for the quality and reputation of a journal (e.g., ABS, 2010; Harzing, 2010). The Greek academic community, despite the deep historical roots that place strong value on intellect and knowledge creation, has not yet even reached the stage to apply for Thompson Reuters indexing of a journal (in fact, there are very few academic journals to have been founded and edited by the Greek academic community, with none of them having achieved even minimal external recognition).

Another benchmark are countries that are located in the same geographic region as Greece (the Balkan region) with shorter modern histories that have been under communist regimes and through traumatizing recent historical events, such as Croatia, Slovenia or Serbia. Despite that these countries have had gruesome recent histories [i.e., they were involved in war throughout the 1990s (e.g., see Malesevic, 2002)], their academic communities managed to develop journals of such quality that Thompson Reuters considered worth indexing. To the contrary, despite its remarkable history of intellect and the fact that it has been by far the strongest economy in the Balkan region throughout the years, the Greek academia has not achieved but minimal recognition by international standards (at this point it is important to reiterate that this holds for the Greek academia as an entity based, operating within and representing the Greek State Higher Education institutions, and by no means does it apply to individual Greek academics who, normally as expatriates or immigrants in other countries, have produced and are still producing work that is internationally recognized).

Two potential explanations ensue for the much below parity contribution of Greek academia into the international scene: academics who are employed in Greek Higher Education either (1) lack the capacity or (2) lack the motivation to engage in research-related activities that advance their fields. Both accounts apparently contain truth. What happens is that the careers system in Greek academia is ruled in such a way that, first, mostly precludes academics with abilities or potential to enter and, 
especially, advance into the system; and, second, does not reward achievement in research or in other academic-related domains (e.g., excellence in teaching). Entry and progression into the system is mostly determined by a-priori membership into an "in-group" (that includes families or extended networks of families that are connected via friendship, political and business ties), with quality of work either being irrelevant or playing minimal role in the course of the career. This system essentially filters-out those with academic ethos and capacity and allows in only individuals who are already connected with the "in-group" or who are willing to conduct themselves in ways that earn the acceptance of that "in-group" who rules, or in fact "owns", academia in Greece.

The following sections inform on certain cultural characteristics of Greece that contributed to the way careers evolve within the Greek academic system. In addition, some information on employment legislation and the physical geography of the country will be provided, as these also have contributed and contribute to the formation of the labour market in Greek academia.

\section{Culture}

Cultural factors that bear special relevance to careers in Greek academia are: the "in-group -outgroup" polarization, the profile of the country in the cultural dimensions of Institutional and In-group Collectivism, the pivotal role of political ideology in life in Greece, and the very strong standing of academics in the Greek society.

\section{In-group - out-group polarization.}

Although the in-group - out-group distinction plays a role in virtually every culture, it occupies a dominant role in the Greek society (Triandis, Vassiliou \& Nassiakou, 1968; Bozionelos, 2006). In particular, those who are viewed as members of the in-group (or "our people" according to the Greek expression), are treated with warmth and are provided with strong support and favoritism by their fellow in-group members; whilst those who are perceived as members of the out-group (or “outsiders"), are viewed with suspicion and treated with overt hostility (Broome, 1996; Triandis et al., 1968). In every-day life Greeks automatically categorize others as members of their in-group or out-group, and adjust their behavior accordingly (Broome, 1996). In addition, because neutrality is 
normally interpreted as "out-group" membership, it has consequences that are similar to overt "outgroup" membership. As a result, in- or out-group affiliation is a cultural imperative that plays major role in individual outcomes. Being part of the "right" in-group (which can be an extended family or a political party) can be extremely beneficial for social outcomes (such as career and life success) and vice versa. The in-group normally includes the immediate and part of the extended family. But in most cases it extends to networks of families with strong friendship ties between them due to common business interests and political ideology. In fact, according to some accounts Greece is owned and governed by a few thousands of families (Kavathas, n. d.; see also bankingnews., 2012).

\section{Institutional and in-group collectivism.}

Pertinent to the way careers evolve in Greek academia is also the profile of Greece on the cultural dimensions of Institutional and In-group Collectivism that were identified in the GLOBE study (House, Hanges, Javidan, Dorfman \& Gupta, 2004). Institutional Collectivism denotes the extent to which people view their fates as inter-dependent with the fate of the collective and are willing to sacrifice personal convenience and wealth for the interests of the state and the community. Greece scores very low on this dimension (Gelfand, Bhawuk, Nishii \& Bechtold, 2004) - in fact, it falls into the last position of all ranked countries. This essentially means that Greeks consider their own fates as independent of the fate of the state itself, and they are unwilling to abide to laws or even ethical guidelines if they do not see these as directly compatible with their own personal interests. On the other hand, In-group Collectivism signifies whether members of a society identify themselves most closely with particular groups (which can include family, friends, or the political party to whose ideology they subscribe) rather than with the whole society or the state. Greece scores moderately high on that dimension (see Gelfand et al., 2004). In-group Collectivism is also linked with the importance attached to the "in-group" (being greater in countries towards the high pole of the dimension), which, as seen, is a particularly pronounced cultural feature in the Greek society.

The profile of Greece on Collectivism, therefore, suggests a country where people act in ways that put their own or their in-group's interests (financial, power, influence, status, etc.) above the 
interests of the collective. Institutional Collectivism is associated with greater social responsibility (e.g., Waldman, de Luque, Washburn, House, Adetoun, Barrasa et al., 2006), while In-group Collectivism relates to low trust at societal level (Realo, Allik \& Greenfield, 2008) and greater levels of corruption and adoption of unethical practices (Mazar \& Aggarwal, 2011). In line with these empirical findings, Greece ranks on the top of all 27 European Union countries on corruption, and finds itself below the median position in global transparency rankings (Transparency International, 2012).

Corruption means "misuse of office for personal benefit" (Soot \& Rootalu, 2012, p. 32). Typical cases of corruption involve public officers who set operations with small networks of family members or trusted others, that is an "in-group", in order to utilize public resources for own private interests and/or favour relatives and friends into appointments. Given that the Greek academia is embedded into a cultural environment that is conducive to such scenarios it would be unnatural to operate in a different way. However, what is intriguing in this case is that the extent of the operation is such that the whole Greek academia is in essence "owned" by an extended "in-group" that is composed of individuals who are connected with blood, family or personal friendship, and political party ties.

\section{The standing of academics in the Greek society.}

Another cultural factor of relevance is the extremely high standing academics enjoy in the Greek society. ${ }^{1}$ This is probably rooted to the strong role of intellect in ancient Greece that has descended as value for education and intellectual achievement into modern Greece. Indeed, having an academic position is highly prestigious for the individual and his/her family, who are respected in social cycles and by virtually all institutions. As illustration, in the most recent single-party government of the country (2009-2011) a substantial number of Secretary Generals and Deputy Ministers were academics who were affiliated to the governing political party. Hence, an academic position provides extremely strong societal status, opportunities to influence affairs, and financial opportunities. 


\section{Employment legislation and academic pay.}

The above cultural feature has, however, consequences that go beyond the effects of simple societal status and extend into actual legislation. Universities in Greece are attached to the state, and employees in them fall into the public sector. Employment legislation for the public sector in Greece includes guaranteed lifetime employment (e.g., OECD, 2012), and an excellent medical cover for the individual and one's family. The privileges for academics, however, go much beyond. In particular, academics have always been granted elite status amongst civil servants in Greece (the title reserved for them is "special functions officers"). As such, academic pay is included into the "special payrolls" section in the State payroll legislation, which means that the wages of academics are protected against decreases in pay that may apply to other sectors (Journal of the Greek Government, 2003). ${ }^{2}$ As an example, academics have been largely exempted from the severe salary cuts that have been part of the recent austerity measures in Greece, and to which all employees directly or indirectly connected with the public sector have been subjected (e.g., Carassava, 2013). ${ }^{3}$ This also contributes to the attractiveness of an academic career in Greece.

However, another financial attraction to being an academic in Greece is the opportunity, always as member of the "in-group", to use the Higher Education Institution and its resources as personal property in order to run one's own personal business. For example, to run one's own taught graduate degree or consultancy/practice. As to be seen in more detail later, taught graduate programs in Greece are at cases owned and run by particular individuals for personal financial profit.

\section{Political ideology and political party affiliation.}

Political ideology has been of paramount importance in the Greek society throughout the history of modern Greece and has been a major determinant of social affairs in the country. Its impact is reflected on the constant explicit and bitter conflict (further instigated by the profoundness of the ingroup-out-group mentality) between groups that espouse different political views. As an example, Greece was the only European country to resort to civil war (1945-1949) in order to settle the transition from the governance of the Axis occupation forces back to governance by domestic 
political forces. That civil war ended with domination of the parties backed by Capitalist-led economies under the NATO Pact over the forces backed by Communism-led economies, under the Warsaw Pact. Not only did that war cause huge devastation (e.g., Carabott \& Sfikas, 2004), but it also impacted and still impacts the social and economic life of the country. For instance, citizens who overtly opposed the conservative political ideology were officially persecuted (imprisoned or even executed) and excluded by civil service (which includes academia) and armed forces careers from 1949 until 1974 or 1981, depending on the account one chooses to follow - though the system was not officially abolished until 1989 (e.g., Pakalidou, 2009). Political ideology and political party affiliation remains the only criterion for entry into the civil service (to which the higher education sector is attached), and for ascendance or appointment into senior positions in the public sector. ${ }^{4}$ Until the early 1980s a prerequisite for earning an academic position in Greece was a proven family record of conservative political ideology; and since the mid-1980s a major asset is either membership or overt ideological support of one of the major political parties.

\section{Geographic context.}

Greece has an ideal climate (mild winters and tolerably hot dry summers), and boasts one of the largest numbers of days of sunshine (e.g., climatemps., 2013). The morphology of the country also has substantial natural beauty, an extended coastline with many accessible islands, and a "friendly" sea (the sea that surrounds the continental part of Greece is often described as a "swimming pool").

The above cultural (i.e., the standing of academics), legislative and geographic characteristics make an academic position in Greece very appealing both for Greeks who live in Greece but also for many Greeks with careers abroad. A factor that adds to that attraction is the strong ties between children and parents in Greek society (e.g., Dimou, 1975; Fokkema, ter Bekke \& Dykstra, 2008), which makes many Greeks reluctant to move permanently abroad and those who are abroad to feel obligation to return at some point to take care of their aging parents. 


\section{Theoretical Background: Social Capital and Intelligent Careers}

The construct of social capital (Bourdieu, 1980, 1986) and the notion of Intelligent Careers were deemed helpful in accounting for the mechanisms that govern how careers unfold in Greek academia.

Social capital signifies resources that include information, influence and solidarity that individuals have at their disposal by means of their relationship ties within a particular social structure (Adler \& Kwon, 2002; Kim, 2013). Social capital exerts its effects by means of two properties, substitutability and appropriability. The former means that social capital can act as a substitute for resources the individual may be lacking, like credentials, skills and abilities, or actual output; while the latter means that the same tie can serve as a provider of multiple resources, e.g., a friend can provide us all, information, solidarity and access to influential others (Adler \& Kwon, 2002). Empirical evidence suggests that social capital enhances individual career prospects. For example, social capital increases the probabilities of entry into employment (e.g., Jokisaari \& Nurmi, 2005) and of career advancement (Seibert, Kramer \& Liden, 2001). Since its early days, and especially after systematic research on its positive effects saw the light of publicity, social capital has been praised for its beneficial effects not only for individuals, but also for organizations and collectives. And career actors, managers and firms have been encouraged to include the building and exploitation of social capital into their agendas (e.g., Burt \& Ronchi, 2007; Cotton \& Shen, 2013; Prusak \& Cohen, 2001).

Much less attention, however, has been paid at the potentially negative consequences of social capital. And it is only recently that scholars have called for systematic attention at the "dark side" of social capital (Teagarden \& Schotter, 2013; Van Deth \& Smerli, 2010). Indeed, looking at sport governance, Numerato and Baglioni (2012) observed that social capital may indeed benefit particular individuals and groups who share and utilize it to advance their own interests (i.e., acquisition of power and material resources). However, this may run against the interests of the sector or the whole society who are in fact eventually harmed because inappropriate individuals advance into positions of power and because resources and prizes are not awarded or won on merit (Numerato \& Baglioni, 
2012). The present work contributes towards this direction, as it illustrates how social capital is utilized to the career benefit of an "in-group" at the expense of the "outsiders", a situation that leads to the detriment of a whole key sector (Greek academia). Authors suggest that whether social capital has benign or harmful effects largely depends on the broader cultural context (Van Deth \& Smerli, 2010; Lin \& Si, 2010). As to be seen, the present work attests to the legitimacy of that suggestion.

Social Capital is partly incorporated into the Know-whom dimension of the Intelligent Careers notion (Arthur et al., 1995), which poses that for maximization of career prospects the individual must possess Know-why, Know-how, and Know-whom. Know-why refers to values, aspirations and interests that make the person attracted to a particular profession or occupation; Know-how means knowledge, skills and credentials that are required in order to follow the route the Know-why indicates; while Know-whom includes social ties that can facilitate the way towards desired career ends by providing access to needed resources (see also Parker, Khapova \& Arthur, 2009). The notion of Know-whom has been developed specifically for application within the careers framework, while social capital is a more general construct that, amongst others, can also be of value in the study of careers (Baruch \& Bozionelos, 2010). On the other hand, social capital is able to provide the mechanisms (the "why") by which social ties contribute towards the achievement of career outcomes. For these reasons, utilization of both constructs was deemed necessary.

The notion of intelligent careers can, however, serve an additional function in the study of careers in academia: it can provide an indication of which of those three competencies weights more towards career ends, and in what career stage each is most critical. By reason, in academia Knowwhy should mostly play a role in the foundation stage, Know-how should be the dominant competency and should play a major role in all stages, and Know-whom should be only marginally important because entry and progression into academia must overwhelmingly depend on merit. However, as to be seen, in the Greek academia it is Know-whom that dominates by nearly fully eclipsing the Know-how. 
Research Question: To identify the mechanisms that govern career progression and success within the Greek academia (RQ1), and to investigate the relative importance of Know-how and Know-whom (RQ2).

\section{Method}

A number of methods aided in the collection of the information for the empirical part.

Retrospective participant observation. The author has held an academic position in the Greek Higher Education, which rendered him a complete participant. He documented events he witnessed, and he consulted these at a later time. Because he had not considered publication at the time observation took place, the term "retrospective" is appropriate (Bryman \& Bell, 2003).

Discussions that took the form of mini informal interviews. These, for example, were discussions with graduates of Greek universities who the author met in various settings (e.g., business, sports, social life), students enrolled in taught and research degrees in Greek universities at the time the author was serving there, currently serving and retired academic and support staff from the Greek higher education, or Greek academics abroad who either had held academic positions in Greece or had happened to have had experiences with the Greek academia.

Though not devoid of limitations, the above methodology has a number of advantages. A major advantage is that being an active participant (i.e., another academic within the system) pretty much assures that what the author directly observed and was narrated or told was unpretentious and represented what actually happens within the system (e.g., see, for example, Numerato \& Baglioni, 2012). Furthermore, the fact that the author at the time had not considered authoring a manuscript adds to the validity of the method because it means that he did not have any motives or particular theoretical frameworks in mind that could in any way colour or distort his observations (Bryman \& Bell, 2003).

A potential caveat of the method pertains to the reliability of the author's retrospective recall. However, studies suggest no difference in the reliability of retrospective and non-retrospective recall (Brockner, Konovsky, Cooper-Schneider, Folger, Martin \& Bies, 1994; Miller, Cardinal \& Glick, 
1997). Furthermore, there are conditions that further enhance the reliability of retrospective recall. These include the absence of pressure on the person to recall, and the focus on the recollection of facts or narrated incidents rather than the author's attitudes, beliefs or judgments at that time (Hardt \& Rutter, 2004; Miller et al., 1997). Both of these conditions were met: the observer and researcher was in absolute control and at ease with his recollection endeavour, and what was recorded and recalled represented facts and events (whether observed by or narrated to him). In addition, having documented these as notes further increased confidence on their reliability (e.g., Middendorf \& Macan, 2002). As a further step towards validity, the author chose not to utilize within the manuscript any cases that directly involved him. This reduced the probability of bias in the recording and recall due to, for example, emotional interference (Porter, Spencer \& Birt, 2003).

Published books, TV Documentaries, and Cases publicized in the media (e.g., newspapers or internet sites). Most of these cases are fully verifiable. These cases, however, were treated only as secondary data, and were utilized only for additional support, in the form of backing references, to corroborate facts, cases and conclusions that were based on personal observations of the author.

All cases that appear in the manuscript, apart from two (Cases \#2 and \#8), were either directly observed by the author or narrated to him by at least two independent individuals (that sometimes included the actors in the cases) during his stay in the Greek academic system. As it will also be stressed below, these cases represent only a portion of the observations of the author. In addition, the author had personally encountered or co-existed with all focal individuals who are involved in these cases. This removes the possibility that the cases or the persons involved are "urban myths" within the system. Case \#8 is special in the sense that the author did encounter the focal individual and many other individuals who are apparently involved, but he cannot confirm the trueness of what is widely alleged (i.e., that the undergraduate qualification was concocted). Nevertheless, the dates and institutions that appear in the official $\mathrm{CV}$ of the focal individual render that allegation plausible, hence, it was considered appropriate to include the case. Case \#2 has been heavily publicized into virtually all media in Greece plus there is a record in the minutes of the Greek parliament. 
It is critical to bear in mind that the cases that appear in the manuscript are only a representative sample of what the author observed or became aware of through narrations. The number of cases and situations the author directly observed or was informed/narrated about was multiple to what is presented in the manuscript. The cases that were chosen for inclusion in the manuscript were those that were judged to be most illustrative of the various aspects of career patterns in that particular context. But every such case must be viewed as a sample of many others the author happened to become aware of.

Following from the above, what is important for the reader to keep in mind is that the widespread nepotism, familism and cronyism in Greek academia is a "truism" that is an undisputed fact within Greece. Indeed, there are scholarly books that have been dedicated to the phenomenon (i.e., Lazaridis, 2008a; Moutsopoulos, 2007), albeit published in Greek only. To these one should add an extensive prime TV documentary (Bloutsou, Kontargiri \& Zarkadas, 2010). These sources, especially the books, have been heavily consulted and utilized towards the development of the comprehensive account of careers within Greek academia the work at hand attempted. This reiterates the point that the cases presented in the manuscript (and in fact the whole number of cases the author encountered and became aware of, which approach one hundred) should be seen as illustrations or instances of various aspects of a widespread phenomenon that is widely known and undisputable within Greece and by those outside Greece (i.e., Greeks abroad or non-Greek scholars who have long experience with the Greek academia) who are strongly familiar with the situation. This is very important because it dramatically reduces a potential criticism of the present work, which is the ability to generalize from a relatively small number of cases.

To protect anonymity, actors are indicated as males, and disciplines have been changed. In addition, initials have been randomly generated from the Latin alphabet.

Data were analyzed for insights they offered about careers in the Greek academia. The primary data were those collected directly by the author (observations and narrations to him). However, the scholarly books and media documentaries and reports were also valuable because they enabled 
corroboration. Primary data were categorized according to career stages because that enabled a temporally structured account of career progression and its patterns. In the next stage, theories were invoked according to their capacity to provide explanations for the patterns indicated by the data. This led to the conclusion that the social capital approach along with the Intelligent Careers notion were the most appropriate frameworks to account for career progression within the Greek academic system; taking into account the cultural and legislative context in which this is embedded.

\section{Findings}

The reporting of the findings will be structured in the following way: First, some fundamental facts about the Greek Higher Education system in general and about the structure of the labour market for academics, including the direct involvement of political parties, are presented; because these play a vital role in the way academic careers evolve within that context. This will be followed by an account of the flow of social capital within the upper ranks of Greek academia, as well as between these, the political parties and the aristocracy of the country; and the meaning of this for employment and career progression within academia. Then there is a historical account of the circumstances that along with national cultural features led to the establishment of the "in-group" and its ruling of Greek academia. Subsequently, what is presented are the methods and mechanisms that the "in group" employs to control the entire career system. That part was organized according to the stage notion of careers because that enabled the development of a clear and comprehensive picture of the major issues at various key stages of career progression: from pre-entry and entry into the system until the late career stage and what this signifies for "in group" members and for those “outsiders" who eventually reach it.

\section{Basic Facts about the Higher Education System in Greece}

The only Higher Education institutions within Greece that are officially recognized by the Greek State are the institutions that are directly attached to and controlled by the State (Greek Constitution, Chapter 16). Non-State institutions were not even recognized as entities (i.e., did not officially exist) until very recently that the State allowed them to function as "centres of liberal studies" provided 
they meet certain criteria (Journal of the Greek Government, 2011). However, the diplomas they grant are only recognized as certificates of attendance and do not have any degree status as far as the Greek State is concerned. This means, for example, that having a diploma from a non-State institution does not count if one applies for a position in the public sector, of which academia is part. The prestige and favourable conditions attached to academia in Greece apply only to State institutions and to academics employed within these institutions.

\section{The Official Structure of the Labour Market in Greek Academia}

The Greek academic system is controlled by the Ministry of Education that is, in essence, by the government. The system is inherently very complicated. Not only this, but there are also frequent changes in minor or major parts of it and frequent special decrees. It addition, it is accompanied by numerous minor regulations that make it labyrinthine. The system is fully centralized in the sense that all regulations and procedures are imposed by the government and the employer of everyone who works in academia is directly the State. This means that every action that relates to the internal labour market (e.g., creation of a new position, promotion, etc.) must receive the approval of the Ministry of Education. However, and as naturally happens in heavy bureaucratic structures, government administrators - even if one assumes that they are impartial - can only check whether procedures and other related issues (e.g., deadlines) have been adhered to and not their content and essence. For example, government officers can check that hiring met regulations with respect to deadlines, format of evaluation reports and composition of the electorate, but cannot check whether candidates were fairly accessed.

On the other hand, the paradox is that controls for those in who are in the governance of Higher Education institutions are virtually non-existent. For example, there are no externally-based structures to supervise the rector (the equivalent of the rector in the UK system is the vice-chancellor and in the US system is the president) or the vice-Rector or the Senate. And because there is tenure for everyone in the grade of Associate Professor and above plus no external performance criteria this 
means that those in the upper hierarchical levels of universities have basically no accountability. ${ }^{4}$ The fact that those individuals have normally roots in the aristocracy of the country plus/or connections with the major political parties further diminishes any accountabilities they may theoretically face. Finally, it should also be noted that higher education institutions in Greece are exclusively run by academics. Support staff and functions (including the Human Resources function) have absolutely no substantive executive power and their role is purely operational.

\section{The involvement of political parties and the political elite.}

Another key fact is the direct involvement of major political parties into the life of the university, in line with one of the key cultural characteristics of Greece. For example, student representatives of political parties are members of the Assembly of each academic department, are invited to provide their views on candidates for academic openings, and are able to vote on certain issues (e.g., Mantzoutsos, 2008). ${ }^{5}$ In essence, this means that political party affiliation can "buy" favourable treatment for those in academia. For this reason those at the upper ranks normally have direct links with the governing party or other strong political parties; links that have usually assisted their career progression. In addition, strong links with major political parties facilitates implementations of personal agendas and offers "protection" (e.g., Moutsopoulos, 2007).

\section{The "In-group" of Greek Academia: Social Capital and its Flow}

Those who are in the upper academic ranks (to be referred to as the "Professoriate") and in the governance of Higher Education institutions in Greece tend to be connected via quite strong ties: these are normally ties due to kinship, long-term family connections, affiliation with the same political party, and less frequently long-term personal friendship and mutual obligation; or in most cases a mixture of these. Hence, there is substantial social capital flowing through the medium-upper and top academic ranks of universities. In addition, that social capital extends to the political and economic elite, because, as noted and as will be described in detail below, academics in Greece generally tend to come from backgrounds of certain wealth and influence and/or to have some kind 
of political affiliation (until the 1980s that had to be with the conservative or ultra-conservative party and since then with any of the influential political parties).

Hence, the social capital the flows within the powerful ranks of academia can arguably be characterized as bonding social capital (see Putman, 2000): networks that connect ties are exclusive and homogeneous in the sense that they contain individuals with common family and educational backgrounds, as well as interest and affiliation with politics; and the binding material is norms, trust and reciprocity that are reserved nearly exclusively for other members of that "in-group". On the other hand, there is limited bridging social capital (Putman, 2000) that is an absence of ties that lead to regular exchange of meaningful information, ideas and trust with "outsiders", who can be, for example, doctoral students or Greek academics abroad who do not share similar aristocratic backgrounds or political connections or both. These "outsiders" are normally kept at bay from the boundaries of that "in-group". Social capital in Greek academia, therefore, partly operates as a mechanism of social exclusion that is of preventing those who are perceived as "outsiders" from entering into the system (Portes, 1998).

Social capital provides the "in group" with information (e.g., potential job openings, budgets of the government, the "movements" of other individuals), influence (e.g., access to the government and/or the ministry of education, ability to influence a selection decision in favour of their own preferred candidate in another department or another university) and strong solidarity. The last is a product of the predominantly bonding nature of the social capital that flows within the "in group", and is critical because it preserves the system: as long as actors honour the norms and conventions of this "in-group" they are allowed to carry out their personal agendas. These agendas may include: bringing or advancing people from their own family or friendly families into the academic system; establishing and running their own taught graduate degrees or other private businesses/practice for personal financial profit; non-conformance with basic obligations (e.g., not showing up for teaching or being absent for very long periods of time without any justification); and a number of other activities, such as forcing doctoral students to work as their secretaries and teach their classes (a 
widespread practice), or utilizing resources of the institution for personal reasons. These in some cases are associated with grotesque events:

B. M. has been a Lecturer in the university for two years. His office is next to the office of a colleague from another department who has a long tenure and the reputation of "being permanently absent from the university". This means that he is never seen around and that his classes appear only "on paper", that is they appear in the timetable and in the curriculum but they do not actually take place (this is not uncommon in Greek universities). B. M. has heard that this individual has ties with the government which, amongst others, means "protection" from the Professoriate; hence, this is not something he would like to "mess up with". One morning B. M. hears some noise from the office next door and then a knock on his door. It is his office neighbour who worryingly utters "we have been burgled!". B. M. was surprised at first because he did not notice anything unusual or missing from his office nor did he hear any other colleagues mentioning anything. Then he recalled that they had been burgled more than six months ago and everything became clear: simply his neighbour had not been into his office even for a single day for more than half a year. Not because he was on any kind of leave but simply because he was silently exempt from any obligations. [Case \#1]

And if someone tries to oppose, let alone change, this situation, this person normally faces the consequences of the solidarity resource of social capital: a united front that is composed of the "ingroup" and includes the Professoriate and the governance of the institution, and often the Professoriates of other institutions, government officials or political parties, and part of the aristocracy. If the previous case [Case \#1] was "amusing", the following case is less so because it grimly illustrates the power and solidarity of the "in-group" that controls Greek academia and the unaccountability that are in essence granted:

Motivated partly by his personal values and partly by pre-election pledges of his political party about tackling corruption the Deputy Minister of Education in the period 2009-2011 declared "war" at nepotism, familism and cronyism in Greek universities (Panaretos, 2010). As first step, the Ministry officially asked the rectors to provide all names and records of faculty members in their universities who belonged to the same family for inspection (Esos, 2010). Given that this was an official demand of the Ministry, and that the employer of all academics is the State, one would expect that this demand would be satisfied with efficiency. Alas! The whole academia severely criticized the Minister for his tactics and accused him for intentionally slandering academia (Edu_gr, 2011a; K $\Sigma \Sigma v \lambda \lambda$ ó yov $\Delta$ EП

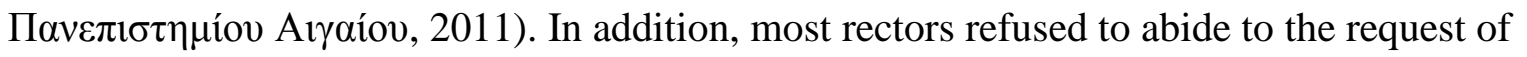
the Ministry (Tsilivarakis, 2010). [Case \#2] 
The "outsider" in the case was the Deputy Minister, against whom the whole academia was united to protect itself from the seeming assault to the status quo. The academic "in-group" has strong connections within the major political parties. In addition, the ties extend to wealthy families with business tradition (that is part of the aristocracy of the country) and with further connections to the political parties (Moutsopoulos, 2007). This, in essence, grants them invulnerability even to the government itself, as the case profoundly illustrates. ${ }^{6}$ A similar thought of the Minister of Education of an earlier government (2004-2007) was contained by the "in-group" long before it translated into any action or even action intention (Kalimeri, 2009). If the Deputy Minister or the Minister has in essence no power, it becomes evident that it would be very unwise for an "outsider" from the lower academic ranks to report any wrongdoing: this would in essence mean the end of his academic career in Greece and potentially even more trouble. ${ }^{7}$ Even innocuous criticism that stays only within is sufficient to cause serious problems:

S. P. was a very bright and hard-working young academic. He completed his first degree and doctorate in one of the central universities of Greece in Athens and after spending the necessary number of years as teaching fellow (due to lack of family or other connections) he was eventually elected in the position of Lecturer in another central University in his mid-30s. During the time he spent as teaching fellow it was of course necessary to include some influential members of that academic department as co-authors in his papers. S. P. had an outstanding publications record for the standards of the Greek academia, including being the leading author in one of the most heavily cited articles that appeared in a premier journal [he prepared the paper entirely by himself, but this is always a trade off those who are not part of the "in-group" have to make, that is to include members of the Professoriate into their own papers]. However, his advancement had been stagnant since. S. P. has the serious "flaw" that he is outspoken. He overtly talks to his colleagues or sometimes in the assembly of the academic department he belongs to about wrongdoings, lack of ethos and corruption within the system. Hence, there is no support from the Professoriate for promotion. Not only that but he has been refused basic rights, like budget for purchasing office and IT equipment. Because of obligations towards his elderly parents and because of being reluctant to expatriate himself after having invested more than a decade in this career S. P. did not want to go abroad. ${ }^{8}$ Nevertheless, and as a reaction, he applied for and was offered a position in the rank of Associate Professor in a major European University (...!). He declined the position, but this led, with a couple of years further delay, to his eventual promotion to Assistant Professor. However, his problems were not over because S. P. had not learnt his lesson and continued to be outspoken. Now, being over his mid-40s he utilized one of the rights offered by the legislation and applied on his own initiative for promotion to Associate Professor. However, 
the recommendation report of the Professoriate (this report is utilized by the electorate for guidance) was negative. To improve his chances, S. P. included a very powerful member of the Professoriate (descendant of a wealthy aristocratic family and with strong connections within a major political party) in one of his top forthcoming publications. This with the hope that that individual would use his influence (this means promises and threats) to persuade part of the electorate to vote in favour of his promotion despite the negative recommendation in the Report... [Case \#3]

\section{The internal labour market: How the "in group" established itself into rule.}

An exploration of the formal structure of the internal labor market in Greek academia at present and historically - having always in cognizance the national cultural context - provides an explanation of how this "in-group" established themselves as complete rulers of the country's academia. The process started decades ago, and has been instigated and nurtured by national cultural features.

\section{Pre-1982 structure.}

Since the establishment of Greek Higher Education in the $19^{\text {th }}$ century and until 1982 only the grade of full Professor was in existence (similar to the system in Germany and in some other Northern European countries in that sense). The position of the Professor, accompanied by a "Chair", was for lifetime. Each Professor had a number of Assistants under his/her rule. Before retirement the Professor would nominate his successor who would normally be one of the Assistants.

Being an Assistant meant living for many years with the hope of becoming the "chosen one" to succeed the Professor. As already noted, until at least the early 1980s political beliefs were explicitly utilized for initial appointments in the Greek public sector, which encompasses academia. For that reason, academics were coming from families that explicitly espoused conservative political ideologies (people with "questionable" politics were not allowed into the system). In addition, these families tended to belong to the "aristocracy" that is they had a background of wealth and connections with the political elite. There were a number of reasons for that: First, only families with the appropriate (conservative or ultra-conservative) political beliefs and affiliations were allowed or provided support (e.g., loans and other forms of facilitation) to do business and acquire wealth. And because of the extreme prestige of academia many wealthy families wanted at least one of their 
offspring to join academia. Second, the route to academia was normally very time consuming (it would take many years to acquire the necessary qualifications, years trying to become an Assistant, and many years as Assistant until one becomes a Professor); and this could be normally afforded only by people who had some financial means of support during that time. Third, the number of "Chairs" was disproportionally small in comparison to the number of Assistants, hence, it was often necessary to have direct connections with the government in order to "influence" the Professor to nominate one's offspring instead of someone else; or sometimes to influence government officials to create a new "Chair" to accommodate their own offspring. Given that until the late1980s there was not even nominal transparency in the Greek government this was many times feasible. Even if a new "Chair" could not be created immediately, ministers or deputy ministers had the freedom to create intermediate posts for the "right" people. The following case is illustrative:

D. G. was the offspring of a well-off family. His family sent him to the US to do his Bachelor's degree and once he finished they encouraged him to do a $\mathrm{PhD}$ and follow an academic career. After completing his PhD he started as Assistant Professor in a US University. However, he found the conditions of work very demanding. In addition, he was missing the social life in Greece and the standing academics enjoy in the Greek society. Hence, he left without tenure in the US and returned to Greece. He targeted a particular central University because his family had family and political connections with the rector. D. G. expected to become immediately a Professor despite being in his early 30s and his credentials were those of an early untenured Assistant Professor in a mediocre US university. Alas, that was in the early-mid 1980s and the academic system had changed to include four instead of a single grade (see below). Furthermore, the political situation was changing and the socialist party that was now into power was working to have its share of people in academia. Moreover, D. G. found out that there were others with strong connections and similar aspirations to him, which meant a long "pecking-order". Indeed, the family friend told him that it would be impossible to give him a full Professorship immediately. Nevertheless, D. G. was not prepared to compromise. His family background had instilled to him the audacity required to perform the following steps: first, he approached others who were in the same situation as him (in fact, many of them were coming from families that had business or friendship ties with each other); and then all of them went directly to the Minister of Education to express their demand. The Minister view that case as an opportunity to place people from his own political party into top academic ranks as well. Hence, he created overnight the position of "Special Scientist". That position was defined in such a way that its holders would be paid nearly professorial salaries and would become preferential candidates for full Professorships once such positions were created or became vacant... Within a couple of years D. G. was a full Professor. [Case \#4] 


\section{Post-1982 structure.}

In 1982, the newly elected self-proclaimed socialist government in Greece changed the academic system (mostly in line with the Anglo-Saxon standards), adopting four grades: Lecturer, Assistant Professor, Associate Professor, and Professor. This system exists until now (though the recent yet-tobe-implemented legislation eliminates the Lecturer grade). It includes a tenure system for the lower two grades. Individuals who enter in any of these grades have to earn tenure. This has to be achieved within six years if one enters as Lecturer and within three years if one enters as Assistant Professor (however, given that processes are sluggish the actual time is normally nine to ten and four to five years, respectively). There is automatic tenure if one enters the system at the grade of Associate Professor or Professor. This, therefore, makes the entry point into the system critical.

Entry into and progress within the system (i.e., hiring, promotion from one grade to the next, and tenure) are accorded by decisions made by an "electorate". The electorate is composed two thirds by academics who belong to the academic department concerned and one third by "external" academics. All members of the electorate must specialize in subject areas ("descriptions of cognitive domain" is the direct translation of the term) that are identical or adjacent to the position under consideration. To illustrate with a simple example, if an Assistant Professor position for the subject "Cell Biology" is open in a particular Department, two-thirds of the electorate must be members of that particular department and one-third must be composed of academics from other academic departments of the same or other universities. All these individuals must specialize in subject areas that are related to Cell Biology and must be at the rank of Assistant Professor or higher.

However, for a few years in the 1980s there was a transition period, when in essence both systems, the pre-1982 and the post-1982, run in parallel. In addition, there had been many special decrees (as illustrated in Case \#4) to fit the needs of particular people that belonged to or were affiliated with the "in group". Such decrees are common until the present days. Apart from serving the interests of those few who are aimed for, these decrees may collaterally assist or sometimes harm "outsiders". This may provide the opportunity to "in-group" members to claim "ownership" of 
certain individuals by means of helping them out in predicaments caused by such decrees, as the following case illustrates:

K. M. was coming from a middle class family and once he completed his doctoral degree abroad and returned to Greece in the early 1980s. Taking advantage of the expansion of academia that the socialist government had introduced he gained a Lecturer position in a central university. Though an outspoken supporter of socialist ideology he had no formal connections with the ruling political party. Furthermore, not being part of the "in group" he was not being kept informed about new regulations and decrees. As a consequence, one day and "out of the blue" he found out that a special degree had been introduced that asked Lecturers to apply for intention to earn tenure. Missing the deadline led to dismissal. As the deadline was very short (this is normally the case with such decrees because they are aimed to cater for the needs of particular "in-group" members or affiliates who are informed in advance about) he discovered that he had missed it. This, in essence, meant losing his position in academia. Given that he had no serious ties with the ruling party or to the government itself he was in anguish. As an act of despair he visited and begged a member of the Professoriate who was of similar age to him but had come directly as full Professor (see, for example, Cases \#4, \#11 and \#18). Though he was coming from an aristocratic family and was affiliated to the conservative party that Professor agreed to help him out. Using his connections he managed to have K. M.'s application considered as it had been submitted on time, and saved K. M. This, however, implicitly meant that K. M. had to be loyal to him in the future and support any of his whims (including voting in favour for any candidates that professor wanted to bring into the Department or the University) [Case \#5]

\section{Dynamics and Mechanisms of Control}

Before proceeding to describe the way the "in-group" rules the internal labour market in Greek academia, two important characteristics of the internal labour market need to be reminded.

First, the system is fully centralized and its procedures are entirely designed and controlled by the Ministry. This means that in every step there must be approval by administrators in the Department of Education. Though approval is in most cases a formality (i.e., what administrators can pay attention at is only surface issues) this makes the process extremely slow. To illustrate, it is normal to take around two years from the point a new academic position is created until a candidate is chosen ("elected"), and then an additional one or two years until the candidate officially starts. Sometimes, however, with membership of or affiliation to the "in-group" this can be substantially "accelerated" (as, for example, it happened with all promotions of the focal individual in Case \#10). 
Second, the law requires that for every candidate an evaluation report must be prepared by a committee of three academics, at least one of whom must be external to the university where the opening exists. The law also requires that for cases that more than one candidate applies, candidates must be juxtaposed in the evaluation report. According to the law, the electorate (see above) has to take into account the report but they are not obliged to espouse its recommendation. Voting is open that is everyone knows what each electorate member votes. This is an important element in an environment such as Greek academia where a power culture dominates; which means that people's actions are normally powered by fear or obligation (Handy, 1976).

\section{How Careers Evolve}

To illustrate how the "in-group" rules and preserve their power base, the stage notion of careers (Super, 1957) has been adopted because it allows inspection of what takes place in all key career stages, including preparation for entry, entry into the system, and progression into it. The model developed by Baruch and Bozionelos (2010) was consulted because it both takes into account current developments and incorporates earlier models. Four stages were considered appropriate to focus on: Foundation, career entry, advancement and gradual change of roles. Foundation and entry were treated within the same section because in the present case they have substantial overlap.

\section{Foundation and entry.}

Foundation is a critical stage in career development because it provides fundamental values, motives and credentials towards a particular occupation or profession (Watson \& McMahon, 2005). In the case of Greek academia, values and motives are instilled by the cultural environment that, as seen, places premium value to educational achievement and to intellect. Indeed, one of the aspired careers of many young people in Greece has traditionally been the academia. This provides the Know-why of the Intelligent Careers notion (Arthur et al., 1995).

The Know-how aspect includes criteria in the form of qualifications and other achievements (e.g., publications) for obtaining an academic position. These should be distinguished into minimal credentials formally required and into additional achievements, such as publications, to earn the 
position. The minimal entry credentials for Greek academia (i.e., Lecturer and above) are set by law and include: doctoral degree, at least two "original publications", and some (not specified in terms of length) teaching experience in the higher education sector. The numbers of publications and years of teaching experience increase with the rank. Another condition is that the candidate must be fluent in Greek. Given that Greek is rare as a foreign language anywhere in the world, this in essence means that candidates are nearly exclusively native Greeks. Though most of these entry level requirements appear relatively unequivocal, the term "original publications" is open to interpretation. The State does not, and cannot possibly, provide an exhaustive list or grading; hence, the meaning of "original publication" and the utilization of lists of not varies according to the "needs" of each case as these are seen by the "in-group". This is illustrated in the following cases:

The particular candidate for promotion from Lecturer to Assistant Professor in a semicentral university has achieved eight publications since he started as Lecturer; six of these were first- or single- authored, and two had appeared in journals indexed by Thomson Reuters. This achievement is much beyond what is expected, and in fact the CVs of many full Professors in that University contained much less. However, according to some members of the Professoriate the candidate has not proved his "loyalty". For example, he had refused to include their names in his papers. In addition, when he had been elected he was an active member of a major political party but he had lately detached himself from political activity. For that reason he lost his support from the members of the Professoriate that are affiliated with that party. Therefore, in either case he cannot be trusted with promotion. If not promoted the achievement of tenure will be under serious threat (failure twice to be promoted from Lecturer to Assistant Professor leads to dismissal). Hence, the idea is to give him a "first warning". If this does not bring him to 'his senses' the next step will include a second failure that will lead to dismissal. For that reason the report inaccurately notes that the candidate has not published in journals that are indexed by Thompson Reuters and uses that to conclude that he has not achieved any publications since he started as Lecturer, hence, he cannot be promoted (...). When in the assessment session the candidate proves that this is not the case, that is he has two papers in Thompson indexed journals (plus many other publications), one member of the report preparation committee invokes a very short list of elite journals that a particular US university utilizes. The candidate has no papers in journals that appear on that list, which the assessor advances as alternative evidence that the candidate has no publications. The electorate overwhelmingly votes against promoting the candidate (...) [Case \#6]

Two candidates compete for entry into the position of Lecturer in a provincial university. One of the candidates has a very strong publications record that contains close to ten articles, including two papers in journals of the elite Financial Times List (“45 journals used 
in FT Research rank", 2012). The other candidate has a very poor record, composed of three papers in unknown journals (i.e., none of them indexed by Thompson Reuters or included in any known or unknown list). In addition, he is not the leading author in any of these articles. However, the former candidate has no connections in the Greek system (he completed his doctorate abroad) neither any political party nor family affiliation with the "in group". While the latter is a blood relative of a powerful Professor in a central university with strong connections in the governing political party and the aristocracy. The report for the first candidate concludes that he possesses no first-authored publications in reputable journals that is "no evidence of ability to conduct research". The report for the second candidate includes that "the candidate has proven his ability to conduct original research of high quality". There is no need to inform the reader which candidate the report recommended, or which candidate was successful... [Case \#7]

The above cases are not extreme. There are many instances where newspaper or popular magazine articles, letters to editors of popular magazines, or even teaching notes for the students that have "counted" as "original publications" (for members or affiliates of the "in-group" that is).

The above clearly suggests that by far the most important aspect in the initial career stages is the Know-whom. This is because the Know-whom substitutes for even basic credentials that the candidate may be missing or lagging behind. As noted, the top and near-the-top ranks are occupied by the "in-group" who share social capital (by means of blood or family friendship ties) that reaches further to the government, the aristocracy, and the political parties. In addition, those individuals control or "own" most of those at lower ranks who are not "in group" members, because if nothing else future progression of those at lower ranks is entirely in the hands of the Professoriate and the rest of the "in group" (see also Case \#5). This means that when academics from lower ranks are included in electorates they have no alternative but to support the candidate who is favoured by their "owner".

Hence, the Know-whom largely operates as a pre-requisite condition for a reasonable chance of entry into the system. Beyond that point, the substitutability property of social capital (Adler \& Kwon, 2002) enables to compensate for other qualities and credentials in the Know-how domain the candidate may be missing; echoing in this sense Coleman's point that "[social capital makes] possible the achievement of certain ends that in its absence would not be possible" (Coleman, 1988, 
p. S98). In fact, there are (apparently rare) cases where social capital has compensated even for lack of basic academic qualifications, like an undergraduate degree, which is something "sacred" within the Greek system:

P. D. was the offspring of a well-off family with political connections. However, he had mediocre achievements at school, naturally was not able to pass the tough entry exams into the Greek university, and until his 30s he had not decided "what to do". His family had enrolled him at a "centre of liberal studies" in Athens from where he graduated (as the reader recalls, degrees of these institutions are not acknowledged by the State). At that point he decided to become an academic. He went on to obtain a doctoral degree from a European university (the circumstances under which he achieved that degree remain "foggy"). However, according to the Greek legislation a doctorate from an accredited institution, as was that European university, is not valid if the individual does not have an undergraduate degree from another accredited institution. This rendered P. D.'s doctorate invalid. Hence, P. D. did not even meet the prerequisite conditions for an academic post in the Greek university sector. Nevertheless, close family friends were in the governance of a central university, and P. D.'s family was strongly connected with one of the major political parties, which also happened to be in power at that time. What they did was to find a connection that the liberal studies centre had with a bottom-ranked US university and to claim that the undergraduate degree and the Master's degree had been earned from that university. They concocted the case such as the dates of undergraduate and master's degree acquisition were very much in the past (when P.D. would have completed his undergraduate studies if he had enrolled along with his cohort) and that university was nowhere in the academic map; hence, in the unlikely event anyone tried to dig into the case it would be impossible to discover facts. ${ }^{9} \mathrm{P}$. D. started as Lecturer and ascended gloriously the academic ladder, took high-profile positions in the governance of the university, and also run his own highly profitable taught Master's course for many years. [Case \#8]

\section{Strategies and tactics for "outsiders" who aspire entry.}

Because it is common knowledge that nepotism and cronyism plays a fundamental role in Greek academia (e.g., Kalimeri, 2009), individuals who aspire to an academic position chose one or all of the following strategies:

(a) completing a doctoral degree in a Greek university. This enables establishment of a personal relationship with those already in the system. Many people who are connected with the "in-group" (e.g., offspring of Professors) follow this route because of its convenience. Indeed, around $80 \%$ of academic staff in Greek universities have completed their doctorates in the academic department they are serving (e.g., Lazaridis, 2008a). On the other hand, this route contains substantial risk for 
"outsiders" because if the individual does not belong a priori to the "in-group" (e.g., does not have family or other kinds of links with the Professoriate or with the government/political parties) there is a strong likelihood that there will be either serious delay or no completion of the doctorate. ${ }^{10}$

(b) For those who already have their doctoral degree, applying for positions as Teaching Fellows (the so-called "407s"), preferably in the University they aspire to earn a position. In this way they hope to gain exposure to the Professoriate, and to demonstrate that they have the appropriate "ethos" and can be trusted. Teaching Fellow positions are renewable on a 6-month or annual basis (renewal is not automatic but involves application anew and consideration against potential competition), are poorly paid (in essence they are teaching assistant positions), and involve "slavery" from the part of the holder. They normally include teaching in excess of what is formally contracted, plus the implicit obligation to include members of the Professoriate in any manuscripts the holder prepares.

Nevertheless, these Teaching Fellowships are seen by many as a way to set the "foot in the door". However, experience suggests that the success of the strategy is rather limited, and when it does this happens after many years or even decades.

D. O. is in his mid-40s, married with one child. He had earned a first degree and a doctorate in Greece by his mid-30s. Since then, and for around ten years, he has been employed as Teaching Fellow in a central university. He is given a new contract every year. The major breadwinner in the family is his wife who works in a bank. He has had no family connections or other ties with people in the upper academic echelons of the Greek academia. For this reason it took him eight years to complete his doctoral degree, and he cannot imagine that he can apply directly for a Lecturer post. Nevertheless, he aspires to an academic career. Though he is a sympathetic to a political party, his standing in the party is not as high to grant him connections within the government or other influential individuals to press for his case. Therefore, he puts his hopes to the sympathy of the Professoriate, to whom he is doing every possible facilitation (including teaching hours beyond his contract, and adding them as coauthors in the manuscripts and conference papers he submits). He knows that he has to prove his loyalty in order to stand any chances for a Lecturer position. Eventually a position opens in his subject area around ten years after he started as Teaching Fellow. However, he finds out that the nephew of a Professor in another Department is also a candidate. Though his cv is clearly superior to that of the other candidate he understands that the evaluation report will favour his competitor. He also knows that, even if that were not the case and the report were objective, the electorate would not dare to vote for him instead of his co-candidate. For this reason he decides to gather all his courage and talk to the Professors he has been working for. What he is promised is that 'if it does not work out this time' he will be the preferential 
candidate when another position arises. This does not do much to alleviate D. O.'s concerns because he knows that he might have to wait five years or more until another position comes out. Eventually, the other candidate withdraws because he is elected in another Department, which he prefers (blood relatives to members of Professoriates have the luxury of choice; e.g., Pylosnews, 2010). Hence, the road now opens for D. O. Due to the sluggishness of the process he eventually takes over his position as Lecturer near his $50^{\text {th }}$ birthday. Until then he continues to work as Teaching Fellow. He also knows that he will have to earn tenure, hence, the process of slavery and ingratiation will continue for long. Nevertheless, he is very proud because he now has a position in academia. The Professoriate also know that they have nothing to worry. He is not "one of them", but he has proved his loyalty, he has been doing the teaching they are supposed to be doing for many years, and he includes their names in his occasional papers. In addition, and maybe most important, he is of absolutely no threat because he will be dependent on them at least until he earns tenure, which will take a minimum of ten years (he will be close to retirement by then). [Case \#9]

In addition, earning a Teaching Fellow position is by no means an easy endeavour in itself. This is because the "in-group" frequently "reserve" such positions for their own people (e.g., offspring or other close relatives). ${ }^{11}$ They do it for two reasons: first, to acquire the minimal teaching experience required by law and, second, to be part of university life until an academic position opens. Another difference from the "outsiders" is that "in-group" members and affiliates stay in these posts for shorter intervals (until an academic position opens) and have minimal obligations.

(c) Directly approaching particular members of the Professoriate to whom they promise "unquestionable loyalty forever". This strategy is normally deployed by "outsiders" who possess both realism and "moral flexibility" and aspire at some point to gain acceptance into the "in-group". The following case is illustrative:

X. M. was in a tenure-track assistant professorship in a medium-ranked US university. However, he was encountering difficulties in meeting the demands for tenure. In addition, he was developing a drinking problem (whose side-effect, amongst others, was the occasional harassment of female students). Hence, he knew that it was imperative to move to a "hospitable" system. However, coming from a middle-class family he had no serious connections with the "in group" of Greek academia. He talked about his quandary with his family in Greece, and his father visited and begged a professor in a central university. That professor occupied key positions in his Department and in the governance of the university, and was notoriously known for his power and connections. The father promised the professor that his son would forever be his trusted servant. That tempted the professor, especially because the begging family espoused the same political ideology as him. However, given that X. M. was not connected to the "in-group" he could not be trusted immediately; hence, he 
would have to start at the bottom to prove his loyalty. This was not an issue for X. M. , hence, he soon started as Lecturer. The choice of X. M. was proved excellent. Not only, as promised, acted as the professor's loyal servant, but the professor also realized X. M. had very similar values to him. For example, he would have no issues with giving false promises, threatening or blackmailing in order to achieve his aims (e.g., inclusion of his name in the papers of others). Neither would he care about his moral reputation. For example, he was glad to find out that X. M. was boasting to his colleagues that "[he] rarely showed up himself in the class, and had never marked a single student script". Therefore, he rewarded X. M. with efficient ascendance into the hierarchy, and X. M. went through all academic grades up to full professor in the shortest amount of time possible (around ten years) - keep in mind, he came as "outsider". The professor also partly saw X. M. as a mirror image of himself, thus made X. M. deputy director in his highly profitable taught Master's program, and later director of that program just before the professor retired. This meant that even from retirement he could trust that he would consistently have his fair share of the profits. That was a win for X. M. too, of course. Not only did he save his career and personal life, but also he has strong standing in the society, he is well-off, and his earned "in group" membership makes him virtually untouchable. [Case \#10]

\section{Strategies and tactics of the in-group.}

It is also important to establish how the "in-group" controls the inflow of academics into the system. New positions are announced by the Ministry, but the grade (or rank) of the position is determined by each concerned Department itself. For example, the government may decide to create two new positions within a particular academic Department of a certain university but the grades of entry (i.e., Lecturer, Assistant, Associate or full Professor) are in essence chosen by the Professoriate of the Department. Reasons for creating new positions are retirement, leave of a member of staff (rare), or "needs".

At this point it must always be borne in mind that there is flow of social capital between the "ingroup", which includes the Professorate, government officials, and other major political parties. Hence, new positions are often "made to custom". For example, a government official may have a family member or a friend or a member of the party who wants to start as academic. For this reason and by means of his/her ties to the university that official comes into agreement with the appropriate member(s) of the Professoriate to create a position especially for that individual (e.g., Piazzadelpopolo., 2010). In other cases, it is the member of the Professoriate who has a relative or 
another type of tie whom he/she wants to bring in. Then in collaboration with the rest of the Professoriate he/she prepares a case for the Ministry or goes directly to his/her political connection in the Ministry or the government.

The point of entry (i.e., at what academic rank one enters the system) is critical because that essentially determines future career development and probabilities to acquire some independence later. Considering that the system contains tenure, which to some extent frees the individual from overt dependency on the Professoriate, filtering in and out those who should and should not reach that stage is crucial. As noted, the process is very sluggish so even if everything evolves well promotion from one rank to the next takes a minimum of four to five years. Most important, because the first two ranks are untenured, entry into any of those ranks means total dependency on the Professoriate for the foreseeable future for those who are not "in-group" members. For these reasons, the general principle in hiring is the following: new people enter at the lowest rank possible unless they are "our own people". However extreme it appears, the core of the mentality of the "in-group" is the following: "If it is feasible to bring a Nobel Prize winner as Lecturer and 'our own people' as full Professors then this is what we will do" $(\ldots){ }^{12}$

A limitation to the point of entry for "in-group" members, however, is implicit controls between members of the Professoriate. For example, a member of the Professoriate may have the desire to bring a relative who has just completed the doctorate as Associate or Full Professor but other members of the Professoriate may oppose it because they consider that this will provide an unfair privilege (internal clashes in the Professoriate are frequent, but eventually there is return to equilibrium because they share interests and social capital, and see each other as part of their own “in-group"). Hence, relatives and friends of the Professoriate who have just completed their doctorates may also start at untenured ranks. However, the difference is that they enjoy very good treatment and a secure upwards career path. The "good treatment" is not only limited to career progression but also to provision of facilities. For example, it is not uncommon, especially in central 
universities, for "out-group" academics to lack access to office (let alone personal computers, etc.) for years after their official start.

Nevertheless, and despite the above limitation, there are still many cases of people with poor or "non-existent" academic records who have been brought directly into professorial positions, as the following case splendidly illustrates:

R. T. was a child of very mediocre abilities and potential. Naturally, he failed abysmally the exams for entry into the Greek University and his well-off parents decided to send him to study in the UK. That was in the 1970s, Greece was not a full member of the EU then, and Greeks had to pay hefty overseas fees to study in the UK. Hence, there were mostly well-off Greek families that could afford this. R. T. managed to enter and complete a degree in a bottomranked UK institution (a Polytechnic, which along with the rest of Polytechnics was named a University with the 1992 reforms of the British Higher Education). Then he enrolled for a doctorate degree. Rumours suggest that he plagiarized his thesis and was allowed to resubmit only in order not to make publicity. Afterwards he found a series of jobs as research assistant in the UK. By now he was in his 40s. At that point a family friend who was Head of Department in a Greek University and well connected with the government created a position of full Professor in his Department and had him elected. The subject area of the position was irrelevant to the area R. T. was pursuing research. R. T. was given by his friend a large office in the top floor of the university building with direct views to Acropolis. R. T. never taught a single class for more than 15 years. Either he did not show up in the class, or he was sending doctoral students or the Department would hire teaching fellows to cover for him. ${ }^{12}$ But he could enjoy the view from his office (when he occasionally visited) and the driving of his sports car around. Because that happened without any pretense it was to some extent scandalous even by the standards of Greek academia. However, no one ever dared to voice even a comment. The fact that his family friends were in key positions (e.g., rector and vicerector) in the university plus his rumoured strong links with major politicians and the aristocracy probably contributed into it. [Case \#11]

A major reason for bringing new people regardless of their CVs at bottom ranks is evident: ability to control new entrants and making certain that only the "right" people will eventually reach tenure much more advance further: having someone entering at the bottom in a system that lacks any substantive transparency means ability to exercise full control over that individual. Due to the attractions of Greek academia, it is generally feasible to solicit and lure talented or established Greeks from abroad. The initial conversation goes somewhat like that: [the Professoriate member is calling the "outsider" who is abroad]: "We find your work of very high quality and we want people 
like you in our Department. An opening is about to come soon, but unfortunately the government has set it at [a rank much below the rank the potential candidate occupies at present or his credentials justify]. However, within three years you will have been promoted to full professor". Of course, the promise is never fulfilled. Normally established academics who are brought this way into the system leave after a relatively short amount of time. Nevertheless, this provides benefits for the "in-group", normally in the form of inclusion of their names into publications but also in the form of teaching relief. Because of the sluggishness of the system it normally takes two to three years from the first "call" until the person officially starts and then normally two to three years until the individual resigns. Inviting and bringing someone into the Greek academia is generally seen as a "favour" no matter the candidate's caliber. Hence, the "outsider" feels obligation, besides asked explicitly, to include the name of the "in-group" member who "brought him/her in" into his/her papers.

"Outsiders" (i.e., not having ties with the Professoriate or the political parties or the aristocracy) at low ranks are attached to member(s) of the Professoriate in their own subject area [these are normally the Professor(s) who "brought them in"]. And they are entirely dependent on those Professors who in essence "own" them. This means that they have basically no rights and can be utilized in any possible way. This usually involves teaching and marking on behalf of these Professors or the rest of the "in group", but also performing other tasks of importance to members of the Professoriate, as the following case illustrates:

M. P. is a newly appointed Lecturer in a central university. He earned his $\mathrm{PhD}$ in a reputable UK university. A member of the Professoriate who runs his own taught Masters' program in the University calls him and demands from him to write the report for the first external accreditation of his program. M. P. has knowledge of this process from his UK experience and is aware that such reports may reach 1,000 pages long. He estimates that it will take him around six months to prepare it. In the UK such reports are prepared by teams of specialist administrators under the guidance of the program leader. M. P. also knows that this demand is completely outside his job description, if not "illegal: ([unlike what happens in every other country of the world] Taught Master's degrees in Greek universities are often owned by particular professors who establish and run these as private businesses for personal profit. These operations are "semi-illegal", and the Professors who own them normally have connections of such nature that allow their activities to be tolerated). But exactly because of 
this reason M. P. knows that he has no alternative. And he would better do a good job otherwise he will have no chances for promotion or tenure whatsoever (...) [Case \#12]

Able "outsiders", provided they start at the bottom, are a necessity and this is something the Professorate realizes. The reasons are multiple:

(1) able people who are untenured are necessary to perform tasks that are not performed by the Professoriate and the rest of the "in-group". A major such task is teaching. Though the law as set by the government requires that all academics perform at least six hours direct contact instruction per week plus any other attached activities (e.g., course administration and marking) many members of the Professoriate or ever of the "in-group" at lower ranks engage in no teaching-related activities at all. Teaching and marking are normally carried out by untenured "outsiders", or by $\mathrm{PhD}$ students who are forced to do it without pay (see also Footnote 9), or by Teaching Fellows (see also above) for whom, however, the budget is limited; ${ }^{14}$

(2) People with ability to carry out research are needed because they add some kudos to the Professoriate by including them as co-authors in their publications. Despite no output requirements in the Greek academic system, most people in it do care about their image as scholars. One of the standard tactics is to approach untenured "outsiders" in their subject area and demand that their name is included into their papers (this tactic is also utilized with doctoral students and Teaching Fellows). ${ }^{15}$ The argumentation normally includes overt or implicit promises and threats.

C. K. has been a Lecturer for around one year in a central Greek University. Before moving to Greece he was an Assistant Professor in an elite UK University. He wanted to move to Greece for personal reasons, and the Lecturer position was the only alternative he was offered. Recently he was given a "Revise \& Resubmit" by a premier journal. Soon after that became known, two members of the Professoriate asked to see him. In those meetings both of them took lengths to explain to him why it would be appropriate to include their names as co-authors in the revised manuscript and why it would be unwise not to do so". [Case \#13]

Regarding already established people, even if these stay only for a handful of years they use the Greek academic establishment as affiliation in their publications (and they normally include some 
"in-group" members in these). This contributes towards the perceived reputation of the institution, and part of that reputation may wear off to the member of the Professoriate who "brought them in". 16 (3) To avoid negative media exposure or to have some argumentative defense (however pretentious) when such exposure occurs. Occasionally the Greek media expose the nepotism, cronyism and endemic corruption (Bloutsou et al., 2010; Kalimeri, 2009, for recent examples). The by-product is that media attention sometimes coerces top officials to intervene (as in Case \#2). Though such interventions normally end in vain or are just ostentatious, they can nevertheless create inconvenience. So it is better to take precautions and do "window dressing" when this is possible. Having some people who are worthy academics provides to some extend such "window dressing".

\section{Controlling the outcomes of hiring.}

At this point one might query how it is possible to have absolute control over the hiring outcomes. The following tactics allow such control:

(1) Academic openings in Greek universities are not widely publicized. By law, such positions must be publicized in the Journal of the Greek Government, which is not easy to obtain (it is available only in one particular point in Athens or needs a special account to access it from the internet). Even if one access it, however, academic openings is only one of the subjects covered, hence, these require substantial effort to discover. In the rare occasions that academic openings appear in any other publications, normally in Greek newspapers, they appear either after or very near the deadline for applications (this is not necessarily intentional, but normally a product of the sluggishness of the system). This is also crucial because the material required for a valid application is overwhelming. It includes, for example, ratified copies of all dissertations and publications of the applicant in numbers equal to the members of the Department to which the application is submitted. ${ }^{17}$ It also demands many official certificates (e.g., birth certificate, copy of criminal record, certificate of military service if male, ratified copies of degrees and certificates of attendance, etc.) that may be difficult to obtain on time - especially if someone lives abroad as it usually happens with "outsiders" who may 
be a threat to "our own people". If a single certificate is not "right" or missing this means automatic dismissal (this is a tactic that is utilized often by the Professoriates in provincial universities to eliminate "outsiders"). The "in-group" candidates are informed well in advance for the opening and have the application material ready. This means that in many cases the only candidate is in fact the “in-group" one (Lazaridis, 2008a; Moutsopoulos, 2007).

2. By means of defining the subject area so narrowly that it fits only into the "in group" candidate and excludes virtually everyone else (e.g. Yiannarou, 2010). There are cases where the subject area of the position extends over many lines and resembles the title of a doctoral thesis or a narrow research subject. In fact, there is a dedicated expression that has evolved in Greece especially to signify this method: "taking the photo of a particular candidate". What follows is the formal subject area ("cognitive domain") of academic position in a central university: "Study (measurement and recording, processing, imaging, surveyance) of the natural space, along with analysis, interpretation and evaluation of the features of the natural and human environment, aiming at the configuration of a complete digital foundation and the participation to the creation of developmental programs with special emphasis to the land registry and earth information systems."

3. By characterizing in the evaluation report "outsiders" as being "out of the subject area of the position". This is complementary to the previous method, and essentially excludes "outsiders" from competition regardless of their credentials. This method is utilized when the "outsider" is overwhelmingly superior to the "in-group" one.

A clearly superior "outsider" is co-candidate with a family member of the Professoriate from another university for the position of Lecturer/Assistant Professor in Organizational Behaviour in a provincial university. This is "tricky" case, because when the opening is for two ranks the law specifies that priority is given by default to filling the post at the higher rank. No matter how much the credentials of the "in group" candidate were stretched he could not fit into the Assistant Professor position because, if nothing else, he lacked the minimal length of teaching experience required by the law. On the other hand the "outsider", however scandalously his credentials were stretched downwards, fulfilled comfortably all criteria for Assistant Professor. So the committee was in serious predicament. At that point, a committee member observed that many of the papers of the "outsider" had appeared in journals that included the term "Management" in their title. This 
resolved their situation. The "outsider" was deemed out of the subject area [because "[he] had not published sufficiently in the OB area but in the Management area instead'], so the only candidate that remained was the blood relative. [Case \#14]

And the following case:

An outstanding "outsider" was candidate for the position of Associate Professor in Cognitive Psychology in a major University in Northern Greece. He had more than sufficient number of publications both in terms of subject content and in terms of journal title to fall within the subject area of Cognitive Psychology; hence, this was very difficult to challenge. However, the committee who prepared the Report noticed that the candidate had completed his doctorate in a Department of Social Psychology. Hence, the Report concluded that the candidate's subject area was out of the subject area of the post, hence, he should not be considered. [Case \# 15]

4. By stretching the credentials of the "in-group member" upwards and the credentials of the “outsider" downwards. Case \#5 provides an illustration of this tactic.

5. Finally, it is not unusual to directly approach and overtly threaten (including physically)

"outsiders" in order to withdraw their candidature (Moutsopoulos, 2007).

\section{Career advancement.}

Once into the system, there are normally three potential fates.

1. For the "in-group" people who join at lower ranks a smooth and certain upwards path. This is normally accompanied, as already touched upon, by minimal requirements for output or contribution. These individuals are sometimes given positions of nominal responsibility that, first, involve prestige and, second, prepare them for assuming positions within the governance of the university later. There are two ways upwards: steady advancement through all ranks within the minimal amount of time required to stay in each. Or accelerated advancement. For example, someone who joins as Lecturer or Assistant Professor may be promoted directly to Associate Professor or Professor, respectively. This is achieved with the utilization of special paragraphs in the legislation (as we noted the legislation is labyrinthine). For instance, there is paragraph for direct promotion to Professor of people who have achieved "world-class" recognition regardless of their present rank or fulfillment of 
other basic criteria (e.g., teaching experience). Exploitation of this paragraph has moved people within two or three years directly from Lecturers or Assistant Professors to full Professors. 2. For "outsiders" advancement normally means a lengthy, uncertain and painful path. These individuals must (a) fulfill their own workload requirements for teaching and administration, and in most cases they also have to cover for the teaching of members of the Professoriate or the rest of the "in-group"; (b) produce significant research output (an endeavour that becomes even more difficult because of the heavy teaching workload and other demands they have to conform to (see, for example, Case \#12); (3) keep the Professoriate and other "in-group" members satisfied and ingratiated. This normally involves (a) including their names in publications (see Case \#13) or even preparing manuscripts on behalf of them, (b) conforming to demands that are completely outside their job description (as Case \#12 also illustrates), (c) supporting their views and proposals in the general assembly, and voting for the candidates they wish to "bring in". If they do not conform their prospects of advancement or even staying in the system drop dramatically (as Cases \#3 and \#6 illustrate).

3. There are some "outsiders" who in the way assimilate themselves into the "in-group". In this case their advancement prospects improve dramatically and eventually their upwards paths resemble those of paragraph 1 above. Case \#10 is representative of this category. A more efficient way, however, is to directly acquire the ties that bridge into the "in-group" by becoming a member of the same family. As the two cases below illustrate this has spectacular career effects:

G. N. had worked for some years in the commercial sector, but in his mid-30s and after changes in his personal life he developed the ambition to become an academic. He had no family or other ties within the Greek academia. Needing a PhD and being aware of the dangers of doing a PhD in Greece he chose to complete it abroad (in a major European country) where he stayed for a couple of years afterwards to accumulate the required teaching experience. Upon returning to Greece he applied initially for lectureships without success. He then turned to the Teaching Fellowship route in order to set the "foot-in-the-door" and develop the necessary ties. Though in a couple of occasions he managed to take Teaching Fellowships in provincial universities, it became clear to him that the likelihood of obtaining a lectureship anytime soon was very slim. What made the situation grimmer was that he had not accumulated any publications record either. And it had already been a few years since he 
had returned to Greece. In a press-conference he happened to meet the aging niece of an extremely powerful Professor in a central University. His marriage with her, soon thereafter, coincided with miraculous improvements in his career prospects. Almost immediately he was successful to earn a Lectureship in a provincial university and in the minimum time allowed by law he had become an Associate Professor. [Case \#16]

K. N. was a Lecturer in a central University. He was finding it very difficult to keep up with unreasonable demands for teaching and with the lack of resources, which had suffocated his research and had kept its publications record to near zero. He was realistic enough to understand that under this situation his future was much below sanguine. In addition, he had no time to enjoy his personal life. His predicament was resolved by marrying the daughter of the rector. Within a handful of years he had been promoted to Professor, and was heading the academic Department he belonged to. [Case \# 17]

\section{Gradual change of roles.}

This is assumed to come at a relatively late stage of life and near retirement. At this stage, for example, after having worked hard and produced for long people may take a lighter workload and act as mentors for less senior colleagues (Baruch \& Bozionelos, 2010).

In the case of Greek academia, however, that career stage often comes either very early in life, for the "in-group", or very late, for the "outsiders". Or it may never arrive for the latter group. For many "in-group" members the tasks and activities that tend to compose academic work are not a requirement. This is either because engagement in these activities is not needed to progress in their careers, or because they reach tenure directly or in a fractional amount of time. After that point there are the following possibilities:

(a) in some cases there is not even nominal involvement in the university, as Cases \#1, \#4, and \#11 vividly illustrate.

(b) in most cases, however, they continue to be involved in the life of the university by means of holding posts in its governance or in academic departments/faculties. This preserves the status quo because it enables them, along with the other members of the "in-group", to control the internal labour market and maintain their social capital. Many of those people also try to present an academic image in terms of occasional conferences and papers. This is normally achieved by means of 
promises and threats to: "outsiders" who are already into the academic ladder, aspiring doctoral students and teaching fellows, and sometimes to gifted "outsiders" who are brought from abroad. (c) in some cases they maintain their involvement mostly from an entrepreneurial perspective. That is they utilize the institution as their own property in order to start and develop their own businesses. This is in the form of taught Master's programs, and practice or consultancy. The strong demand for graduate education in Greece offers this opportunity. Unlike what happens in the rest of the world, a number of Taught Master's programs in Greek universities are owned by single (or small groups of) academics who use these as operations for personal profit. This explains the seeming paradox that multiple taught graduate degrees on the same identical subject (e.g., three MBA degrees) may coexist within the same Higher Education institution - simply, they are owned by different individuals. This is feasible due to the virtually non-existent controls for the "in group" due to the strong social capital that flows between the Professoriate, the political parties and the aristocracy. Hence, there are academics in Greece who essentially operate as businessmen/women by “selling” their own Master's program. The same happens with management/executive education and practice or consultancy (i.e., they use the resources, material and human, of the institution to deliver these for purely personal financial gain). To find people to teach and do the other types of work is simple: academics, Teaching Fellows or doctoral students who either do it for some pay or by force (see, for example, Case \#12 above). The case below is quite comprehensive:

P. G. was offspring to a wealthy family with strong connections in the then permanently ruling conservative party. He failed the entrance exams to the Greek university, but his family could afford to send him to the US to do his degree and then his doctorate. He started as assistant professor in the US but he soon returned to Greece where family friends in the Professoriate of the central University to which he aspired elected him directly in the rank of Professor. That was in his early 30s. During his 30 years of tenure in the Greek university he never taught a single class session (personal accounts of graduates recall that though "on paper" he was teaching classes, in reality they "had never" - and they stress that 'never' "seen him": his classes were either silently exempted or were taught by doctoral students). Instead, he took a full-time position in the governance of a private college (to be clear: he had two posts: fully paid by the State University and fully paid by the private college) plus a number of other positions. At some point a minister - in one of the desperate, ill conceived and doomed acts to limit chaos and corruption in Higher Education - introduced a law that 
staff in State universities cannot hold positions in non-State institutions. At that point P. G. had to eventually, and after attracting media attention, give up his other major position and officially keep only his post in the State university (because that had the most security, benefits and prestige). To continue his lavish life style he "opened" his own Master's degree and his own consultancy service within the university using the resources of the university. Having political connections, family friends in the university governance, and taking up such positions occasionally himself provided P. G. with the liberty to have absolutely no accountability. Further, using artfully promises and mostly threats and blackmail on doctoral students and "outsiders" he was also able to see his name in some papers, so he could boast research activity. In addition, over the years he brought and developed in the university "his own people", either family friends or others who were groomed by him for dependency and loyalty. In this sense, P. R. created a substantial personal kingdom and so he expects that when he formally retires he will still continue to reap part of profits. In addition, he expects that those "clones" of him will help his offspring into its way in Greek academia. [Case \#18]

Cases as the above are not unusual, especially in disciplines that are popular and provide ample ground for graduate education, and practice-related services, such as business-related disciplines.

On the other hand, for most "outsiders" that last stage comes late or never (e.g., see Case \#9). In the occasions that "outsiders" reach a position of independence or power (e.g., tenure or become Professors) "on time" (so they still have a substantial number of years ahead until retirement), there are two major possibilities:

(i) Either they have been eventually eroded by the system, so they are now part of it and act in similar ways as the "in-group", or

(ii) they become "quixotically comical" in the sense that they live in isolation as outspoken critics of the system with no real power to change it and imposing no threat to the "in-group". 19

The following case, albeit rather atypical, is very interesting because it reaches across both of these trajectories:

M. M. was a bright and talented offspring of a middle-class family who upon completing his doctoral degree in a European country returned to Greece to fulfill the ambition to become an academic. That was in the early 1980 s when the socialist party was still fresh in power. He was sympathetic to that party but not strongly organized as a member. In addition, the Professoriates in virtually all universities were still nearly exclusively linked to the conservative party. Nevertheless, using his limited connections and taking advantage of the expansion of higher education at the time he managed to earn a position as lecturer in a central university having spent a short amount of time as teaching fellow. After that, which could be seen as "success", however, he realized that advancement or even survival would be 
a very painful undertaking. Not belonging to the "in group" involved "slavery" as lecturer and a very uncertain future. Despite having a rather exceptional publications record for the standards of the time and context, he had been twice refused consideration for promotion. That made him uneasy not only because of his uncertain future but also because at that time he had some ideals of fairness and meritocracy. However, being very ambitious he concluded that he had no choice but to immerse into the system. Therefore, he deployed his remarkable cleverness to gradually develop and implement a career strategy that was based on two axes: first, formal affiliation with the socialist party (which was in power and enjoyed strong popularity). This provided him with some political protection, but also bridging ties to a new aristocratic cast that was being formed by those who were accumulating wealth due to their ties with the socialist government. Second, he cultivated of a positive relationship with those "in group" members who were roughly his age cohort. Some of them occupied positions in the Professoriate because they had come through the "direct" route, and some in the lower ranks due to the new structure that was implemented in the 1980s. In either case, that "bought" him some "immunity" against the whims of the Professoriate and also reduced resistance to his advancement. Furthermore, that gave him potential access to the conservative aristocracy that was still by far the most powerful in the country. In parallel to those strategies, M. M. took full advantage of the standing of academics in Greece and claimed "world expertise" in an area that was in very strong demand for specialist education (in reality he never published even a single paper in that area...). The protection that his formal involvement in politics offered him along with the tolerance of the Professoriate enabled him to gain access to university resources (human and material, such as teaching rooms) to start his own Master's course but also to run his own specialist education and consultancy services within the university. At the same time, and being very articulate, he was exposing himself to the specialist print media, which provided him with additional routes to advertise his courses but also to further stipulate the image of himself as "world class scholar and expert". The natural trade-off of investing time and energy in the implementation of the above strategy was of course inability to focus on genuine academic activities. However, he had long discovered that such activities do not pay off in Greek academia.

Those strategies worked extremely well and enabled him to advance to the rank of Professor while concurrently he amassed substantial personal wealth. By that time he had been fully absorbed by the "in-group" and the Professoriate despite officially posing himself as a "renegade". For example, apart from his own Master's program, he co-owned Master's programs with professors who were by-inheritance members of the "in group". In addition, his treatment of others was typical "in group" and exactly the same as the treatment he had himself received at the start of this career. That included using doctoral students as secretaries and unpaid teaching assistants, and demanding inclusion of his name in publications. By that time he had in essence abandoned scholarly. His exclusive occupation was the running of his programs and the preservation of the status quo.

However, being now in his fifties he did possess enough awareness to know that for all his wealth, power, and expert image to lay eyes, in reality as a scholar he was a "nobody". And that turned him somewhat depressed. He attempted to correct this by associating his name with potentially influential work. For that reason he approached eminent Greek scholars from abroad whom he tried to ingratiate or to lure with promises for a position in Greece.

Unfortunately that did not pay dividends because the mentality of those individuals (i.e., "a fair share of work is needed to deserve authorship") was very different from the mentality he had long developed. That "failure" brought frustration that apparently was intense enough to lead to noticeably deviant behaviour. That included frequent "eruptions" in public against unprotected "outsiders" while on the other hand he would also publicly burst to denounce the lack of ethos within academia and in public life... That type of behavior eroded his credibility within the university. However, he faced no confrontation: "outsiders" were afraid of and 
depended on him, while the rest of the Professoriate knew that he posed no threat while his interests were inter-whined with theirs. Nevertheless, that deviant behaviour led to isolation: neither "outsiders" nor "in group" members would interact with him unless they had an interest to pursue or a favour to exchange. And that further exacerbated his situation. To escape, and having ample free time at his disposal, he wrote a romantic novel that met substantial commercial success. This gave him the idea to pursue a parallel career as novelist. His career as popular novelist gave him considerable popular media exposure that allowed him to propagate a favorable portrait of himself to part of the lay public. In that period, and as a consequence of the economic situation in the county, major upheavals took place in the Greek political scene. As a result, the political party he was affiliated with fell abysmally both in parliamentary power and in public opinion. Having himself firmly anchored to a host of ties, dependencies and personal wealth, and also having apparently developed a grandiose self-mage, M. M. saw it as an opportunity to start his own political party in parallel to being academic and novelist. Though not taken seriously by anyone in his proximate environment, some "in-group" members and a number of "outsiders" formally declared support to it in case there were gains to reap. [Case \#19]

Most cases are not as complex. However, despite its convolution, the above case is highly illustrative of how talent is wasted and ethos is transformed within the cogwheels of Greek academia.

\section{The Scope of the Phenomenon}

What was presented above is the general average situation with respect to careers in the Greek academic system. The whole academia is essentially controlled, or better "owned", by a number of individuals who form an "in-group" that is connected with strong bonding social capital due to family, business, personal or political ties whose resources (information, influence, solidarity) and properties (substitutability and appropriabilty) allows them to rule the system and their members to thrive. The Know-whom totally eclipses the Know-how, though the other way around is the way it should be. In fact, in some cases, whole academic departments are owned by single families. An illustration is the recently exposed case of a Department in a central university where all academic staff were either direct blood (e.g., sons, daughters, sisters, brothers) or in-law (e.g., brother-in-law)

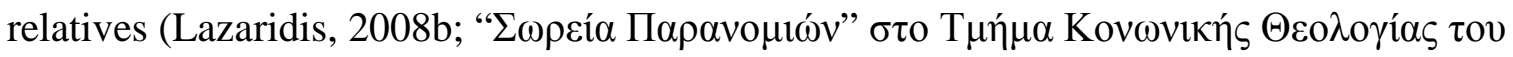

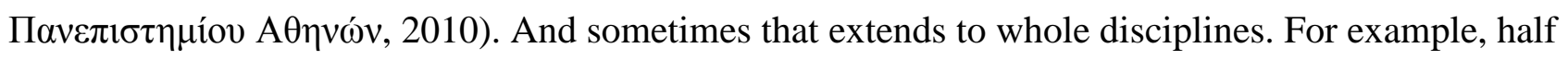
of the academic staff in non-professorial ranks in the major medical schools have the same family name with members of the Professoriate (Adioristos, 2009), and this does not include family members by law (e.g., sons/daughters-in-law) who bear different surnames (Andritsaki, 2010) or 
other "in group" ties (e.g., family friends). If one considers that, via the social capital flow within the “in-group", there must naturally be exchange of family members between universities (see, for example, Case \#7], it clearly emerges that whole disciplines virtually "belong" to a small number of families and individuals affiliated with them.

\section{Discussion}

The work at hand focused on careers within the academic system of a particular country and has illustrated how social capital along with its resources and properties determine careers within that system. As such, the case of Greek academia provides strong support to the social capital approach to career success (e.g., Seibert et al., 2001; and see Baruch \& Bozionelos, 2010). Beyond this, however, the present work suggests that social capital or Know-whom is in most cases a sufficient condition for career entry and success. On the other hand, exclusive reliance on accumulation of Know-how (e.g., publications and teaching excellence), which should presumably be the most valued resource in a knowledge-intensive industry as academia, is unlikely to pay dividends.

The study also demonstrates how an extended "in-group" of individuals who are linked with blood, family, political and business-related ties controls an academic labour market of substantial size (there are well in excess of 40 Higher Education institutions in Greece with more than 400 Departments). Career success within that system is predominantly determined by a-priori membership to that "in-group" or by willingness to accede in exchange for loyalty and service to its members.

The case of the Greek academia also indicates that social capital may entail strong benefits for particular "in-groups" but at the expense of the collective, as illustrated by the under-achievement of Greek academia as a body. By extension, presuming that production and circulation of knowledge is critical for a country, this brings harm to the greater or "macro-level" collective, which is the whole country. This concurs with recent alerts on the "dark side" of social capital, which signifies its potentially negative effects (e.g., Van Deth \& Smerli, 2010). It is worth noting that many elements of the "dark side" perspective are found in a monograph by a Greek academic (Lebesis, 1941/1990) 
much before the advent of the concept of social capital and systematic career theory. Lebesis (1941/1990), who spent his entire academic career in Greece, observed how certain individuals and small groups unethically utilize their relationship ties to circumvent meritocracy and formal procedures in order to achieve personal goals such as accumulation of power, wealth and advancement to office. Lebesis argued that by means of advancing their personal interests these individuals concurrently harm the collective to which they belong, which is becoming increasingly handicapped in the long term. This mirrors the under-achievement of Greek academia as a body.

The way careers evolve within the Greek system also largely accounts for the brain-drain phenomenon (e.g., Baruch, Budwar \& Khatri, 2007), which is a constant plague for Greek academia. Indeed, Greece proportionally has one of the greatest numbers of expatriate academics. Being excluded by the system as "outsiders", most academically talented Greeks choose self-expatriation to eventually become immigrants abroad (e.g., Boulia, 2012). And the proportionately few able ones who stay in Greece eventually focus their energy into developing, maintaining and extending their relationship ties rather than on core academic activities of production and circulation of knowledge; given that career progression is predominantly determined by Knowing-whom instead of by Knowing-how. This also partly explains why the Greek academic community abroad boasts substantial achievements, in contrast to the domestic academic community.

\section{Prognosis.}

As seen, the present situation has roots that reach many decades in the past and is selfperpetuated via mechanisms that are governed by cultural values (i.e., the low Institutional collectivism, the in-group-out-group polarization, the importance of the family, the standing of academics, and the key role of political ideology). These interact to render social capital detrimental. Issues that involve national culture are very difficult if not impossible to resolve (e.g., see Hofstede $\&$ Hofstede, 2005). Furthermore, even if one argues that imposing change in a whole sector, such as academia, is feasible (something highly disputable, e.g., Lewis, 2010; Quinn, 2012), the Greek academia does not operate in isolation but it is linked with the political life and the aristocracy, in an 
inter-connected web. Hence, there is usually no incentive for meaningful change (because this would essentially mean voluntary decision of the "in-group" to discontinue its own existence). As seen, in the few cases the government (or better, single individuals who found themselves in the Ministry) has tried to act this has been in vain. In fact, in certain cases this has facilitated the task of the "ingroup". An example is the legislative rule that a third of the electorate must be external to the academic Department a position is available, which was introduced relatively recently (in 2007) with the stated intention to limit the rampant nepotism and cronyism. In reality this led to a deterioration of the situation because it has granted to the "in-group" the power to legitimately intervene and control hiring and promotions everywhere; and, hence, to establish itself even in relatively "virgin" territories such as newly established provincial universities and departments, or in places where some kind of "revolutionary" activity could be discerned (e.g., Kalimeri, 2009).

\section{Limitations and Directions}

Limitations include concerns over the reliability of the author's retrospective recall and the possibility that observations have the element of subjectivity. Though these should be kept in mind, the particular way data were collected (i.e., the author was a fully immersed participant without having the concept of pursuing a manuscript at the time) and recollected (i.e., from notes that recorded facts and events in which the author was not directly involved) alleviate many of those concerns.

Another potential criticism pertains to the legitimacy of generalizing from a limited number of cases to a whole sector. However, as explained in length, the number of cases presented in the manuscript is only a portion of the cases the author observed or became aware of. In addition, and most important, the phenomena the manuscript uses as a base (i.e., widespread and endemic nepotism and cronyism within Greek academia) have already been documented multiple times within the country, and they do not compose an issue of dispute. Such sources of documentation were 
utilized in the manuscript as secondary data for corroboration purposes. As already stressed, the aimed contribution of the work at hand was the development of a structured and comprehensive account for careers within a particular environment; rather than the discovery or disclosure of a situation.

The present work adds to calls for focus on the darker side of social capital. Scholars (e.g., Lin \& Si, 2010; Van Deth \& Smerli, 2010) have contemplated on the role of the cultural context in the determination of the consequences of social capital. The work at hand suggests that, indeed, when the broader cultural environment meets certain characteristics then social capital may be to the detriment of a whole sector, albeit being instrumental of an "in group". In the case of Greece and its academia those cultural characteristics include the combination of low Institutional and strong Ingroup collectivism, the in-group - out-group polarization, the extreme value attached to an academic position, and the importance of party politics in everyday life.

Future research ought to further disentangle the inter-play between the mechanics of social capital and the cultural context in which this operates. For example, future studies can focus on academias that perform above parity, such as those of the countries mentioned in the introductory part, in order to identify cultural dynamics that may render the total effect of social capital positive instead of negative. For example, particular cultural features may render the social capital that flows within such academias more balanced in terms of bonding and bridging type. That may mean a more relaxed distinction between the in-group and the out-group, a pattern that does not foster nepotism, cronyism and isolating tendencies (see, for example, Putman, 2000; but also Garcia Albacete, 2010).

Quantitative studies can also be of use. For example, future research can quantify the relative contribution of Know-whom and Know-how on career progression and other outcomes within various academias or even institutions within the same academia. And then utilize the ratio of contribution to predict differences between academic communities or institutions in output.

Future research could also utilize network analysis (e.g., Hanneman \& Riddle, 2005) to map the relational network of the "in-group" and develop a deeper understanding of how ties are deployed 
and interact in its various activities; as well as map the territories over which the network of the "in group" extends. In this respect, longitudinal or retrospective data from network analysis may also provide insights into how the relational web of the "in-group" has evolved over the years (e.g., Mastrobuoni \& Patacchini, 2012). This can also provide insights into, for example, how the networks of "outsiders" who eventually immerse themselves into the "in-group" transform over time.

As seen, the findings suggest that careers within the Greek academia follow different patterns. There are "outsiders" who manage to enter the system and advance through their own merit following a very painful and uncertain route but without subscription to the "in-group"; while other "outsiders" choose to sign up to the in-group from the very beginning, or who are eroded in the way. In addition, there are individuals who chose from the outset not to engage at all with the system and instead pursue their careers abroad or within the very few non-State institutions that operate within Greece. The psychological make-up may play a role in the choice of the route one follows, and hence, which pattern one's career conforms to. The construct of psychological capital (Luthans, Youssef \& Avolio, 2007), which is composed of the resources of hope, self-efficacy, optimism and resilience, may be of relevance here. Psychological capital assists individuals to go through adverse social conditions at work while maintaining their focus (Wang, Wang, Fan \& Gao, 2013). Strong psychological capital may, for example, be one of the qualities possessed by those "outsiders" who are able to maintain their efforts and survive within that system despite the multitude of adverse conditions they face. Another construct that can be of relevance is machiavellianism (Christie \& Geis, 1970), which denotes the tendency to pursue one's goals in duplicitous ways and without concern for ethos, for the truth, or for the wider community. Machiavellianism may be able to differentiate between those outsiders who subscribe to the in-group from the beginning or convert in the way from those who persist in the "righteous" path or who leave the system.

It is also important to examine the meaning of the present findings for career theory itself. The present work suggests interplay between different levels. It appears that national cultural features, which can be seen as abiding to a macro-level structural approach, create the conditions for the social 
capital dominance of career outcomes within the academic sector, which is a meso-level factor. This shapes individual careers (a micro-level variable). However, this last one also influences to some extent culture within academia itself (meso-level) but also structure (e.g., whether relevant legislation is actually implemented and even the nature of new legislation, what new positions are created and where), which is another meso-level variable. Future research could, therefore, examine and model the interplay of elements at multiple levels to develop a complete picture of the dynamic nature of careers.

Finally, the present work has methodological implications. If a quantitative approach were utilized (i.e., with scale measures of social capital and network ties, e.g., Bozionelos, 2003) it is unlikely that it would fully disclose the situation and the phenomena that are taking place. It may not have even revealed that social capital plays a strong role in career progression because the vast majority of those who are within Greek academia and enjoy efficient career progression possess strong social capital (which would mean low variance, hence, weak relationships); far less would it reveal of its nature and the way it operates. It was the in-depth awareness provided by participant observation and first-hand knowledge of historical and cultural facts that enabled a full understanding of the situation. This implies that methodologies that involve immersion into the particular context, such as ethnography, may be more apt at tapping the way social capital operates (see also Numerato \& Baglioni, 2012).

\section{References}

ABS, The Association of Business Schools (2010). Academic journal quality guide. London: The Association of Business Schools.

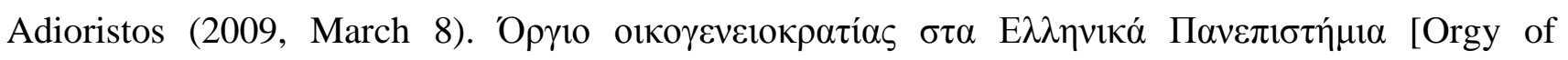
familism in Greek universities]. Adioristos.wordpress.com. Retrieved from http://adioristos.wordpress.com/2009/03/08/

Adler, P. S., \& Kwon, S-W. (2002). Social capital: Prospects for a new concept. Academy of Management Review, 27, 17-40. 


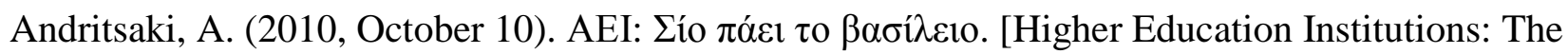

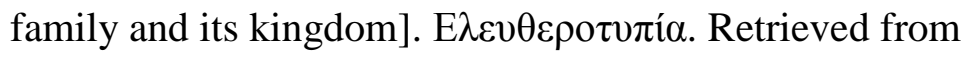
http://www.enet.gr/?i=news.el.article\&id=218182

Arthur, M. B., Claman, P. H., \& DeFillippi, R. J. (1995). Intelligent enterprise, intelligent careers. Academy of Management Executive, 9(4), 7-20.

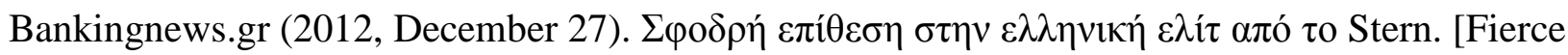
attack to the Greek elite from Stern] [Newsgroup]. Retrieved from http://www.bankingnews.gr/component/k2/item/72043

Baruch, Y., \& Bozionelos, N. (2010). Career issues. In S. Zedeck (Ed.), APA Handbook of Industrial and Organizational Psychology, Volume 2: Selecting \& Developing Members of the Organization (pp. 67-113). Washington DC: American Psychological Association.

Baruch, Y., Budwar, P. S., \& Khatri, N. (2007). Brain drain: Inclination to stay abroad after studies. Journal of World Business, 42, 99-112.

Barzum, J. (2000). From dawn to decadence. New York: HarperCollins.

Bloutsou, V. (Editor in Chief), Kontargiri, D. (Director), \& Zarkadas, G. (Director) (2010).

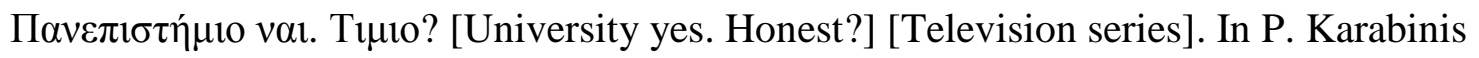

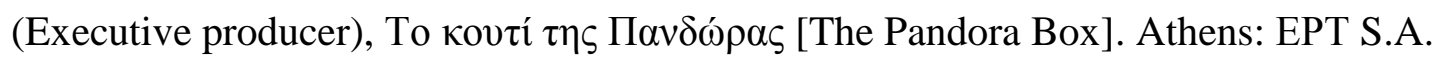

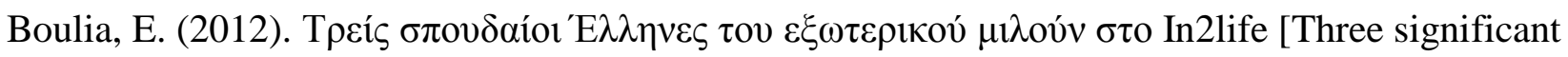
greeks from abroad talk to In2life]. [Newsgroup]. Retrieved from http://www.in2life.gr/features/faces/articles/218443/Face.aspx

Bourdieu, P. (1980). Le capital social: Notes provisoires [Social capital: Provisional notes]. Actes de la Recherche en Sciences Sociales, 31, 2-3.

Bourdieu, P. (1986). The forms of capital. In J. E. Richardson (Ed.), Handbook of theory for research in the sociology of education (pp. 241-258). New York: Greenwood Press.

Bozionelos, N. (2003). Intra-organizational network resources: Relation to career success and personality. International Journal of Organizational Analysis, 11, 41-66. 
Bozionelos, N. (2006). Mentoring and expressive network resources: Their relationship with career success and emotional exhaustion among Hellenes employees involved in emotion work. International Journal of Human Resource Management, 17, 362-378.

Bozionelos, N. (2011). Performance appraisal in the Greek public sector: What happens on paper vs. what [does not] happen[s] in reality. In H. van Emmerik, N. Bozionelos, \& H. Guenter (Chairs), Ways of measuring and monitoring employees' performance and well-being in different cultures. Symposium conducted at the International Conference of the Eastern Academy of Management, 26-30 June, Bangalore, India.

Brockner, J., Konovsky, M., Cooper-Schneider, R., Folger, R., Martin, C., \& Bies, R. (1994). Interactive effects of procedure justice and outcome negativity on victims and survivors of job loss. Academy of Management Journal, 37, 397-409.

Broome, B. J. (1996). Exploring the Greek mosaic: A guide to intercultural communication in Greece. Yarmouth, USA: Intercultural Press.

Bryman, A., \& Bell, E. (2003). Business research methods. New York: Oxford University Press.

Burt, R. S., \& Ronchi, D. (2007). Teaching executives to see social capital: Results from a field experiment. Social Science Research, 36, 1156-1183.

Carabott, P., \& Sfikas, T. D. (2004). The Greek civil war. Aldershot, UK: Ashgate Publishing. Carassava, A. (2013, March 12). In debt-ridden Greece, further military cuts are hard to make. Los Angeles Times. Retrieved from http://articles.latimes.com/2013/mar/12/world/la-fg-greeceausterity-20130313

Christie, R., \& Geis, F. L. (1970). Studies in machiavellianism. New York: Academic Press.

Climatemps.com (2013). Greece. Retrieved from http://www.greece.climatemps.com

Coleman, J. S. (1988). Social capital in the creation of human capital. American Journal of Sociology, 94, S95 - S120.

Cotton, R. D., \& Shen, Y. (2013). The company you keep: The relational models and support expectations of key developer relationships. Career Development International, 18, 328-356. 


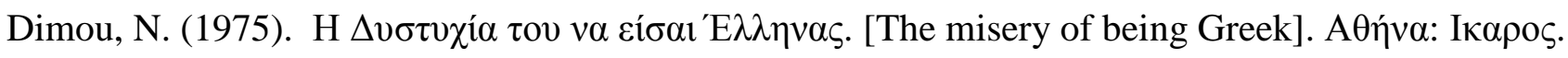

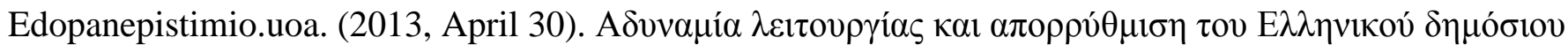
$\pi \alpha v \varepsilon \pi \iota \sigma \tau \mu^{\prime}{ }^{\prime} v$. [Incapacity of the Greek national university to function]. Edopanepistimio.uoa.gr. Retrieved from http://edopanepistimio.uoa.gr/index.php?p=reportage\&id=597

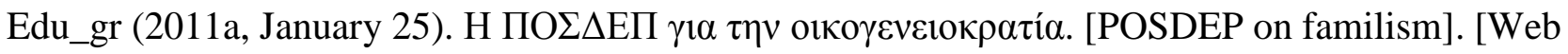
log post]. Retrieved from http://educationingr.blogspot.fr/2011/01/blog-post_25.html

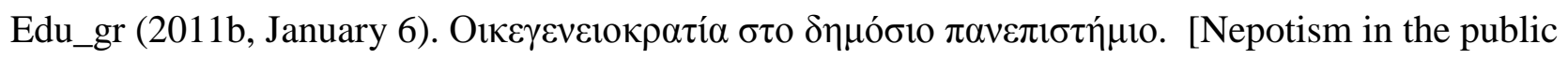
university] [Web log post]. Retrieved from http://educationingr.blogspot.fr/2011/01/blogpost_06.html.

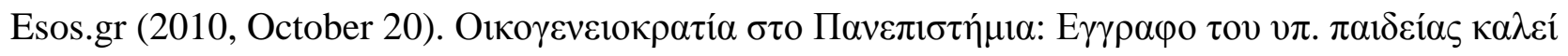

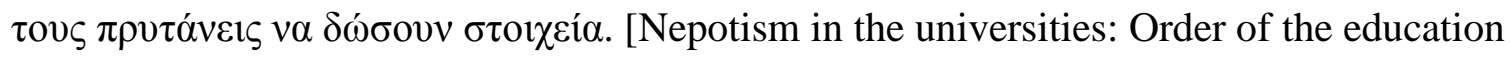
ministry asks rectors to provide information]. [Web log post]. Retrieved from http://www.esos.gr/article/eidisis-defterovathmia-ekpaidefsi/oikogeneiokratia-sta-panepistimiaeggrafo-tou-ip-paideias-kalei-tous-pritaneis-na-dosoun-stoixeia

Finley, M. I. (1985). Democracy: Ancient and modern. New Brunswick, NJ: Rutgers University Press.

Fokkema, T., ter Bekke, S., \& Dykstra, P. A. (2008). Solidarity between parents and their adult children in Europe (Netherlands Interdisciplinary Demographic Institute Report 76). Amsterdam. KNAW Press.

Garcia Albacete, G. M. (2010). The saliency of political cleavages and the "dark sides" of social capital: Evidence from Spain. American Behavioral Scientist, 53, 691-716.

Gelfand, M. J., Bhawuk, D. P. S., Nishii, L. H., \& Bechtold, D. J. (2004). Individualism and collectivism. In R. J. House, P. J. Hanges, M. Javidan, P. W. Dorfman, \& V. Gupta (Eds.), Culture, leadership, and organizations: The GLOBE study of 62 societies (pp. 437-511). Thousand Oaks, CA: Sage. 


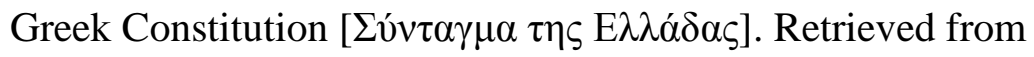

http://www.hellenicparliament.gr/UserFiles/8c3e9046-78fb-48f4-bd82-

bbba28ca1ef5/SYNTAGMA.pdf

Handy, C. B. (1976). Understanding organizations. Oxford: Oxford University Press.

Hanneman, R. A., \& Riddle, M. (2005). Introduction to social network methods. Riverside, CA: University of California Riverside.

Hardt, J., \& Rutter, M. (2004). Validity of adult retrospective reports of adverse childhood experiences: Review of the evidence. Journal of Child Psychology and Psychiatry, 45, 260-273.

Harzing, A-W. (2010). The publish or perish book. Melbourne: Tarma Software Research.

Hofstede, G., \& Hofstede, G. J. (2005). Cultures and organizations: Software of the mind (2nd Ed.). New York: McGraw-Hill.

House, R. J., Hanges, P. J., Javidan, M., Dorfman, P. W., \& Gupta, V. (Eds.) (2004). Culture, leadership, and organizations: The GLOBE study of 62 societies. Thousand Oaks, CA: Sage.

Jokisaari, M., \& Nurmi, J-E. (2005). Company matters: Goal-related social capital in the transition to working life. Journal of Vocational Behavior, 67, 413-428.

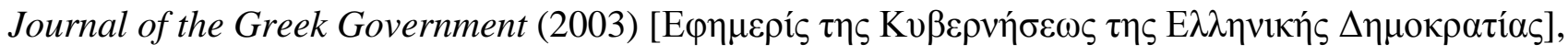
297(1), 5021-5048.

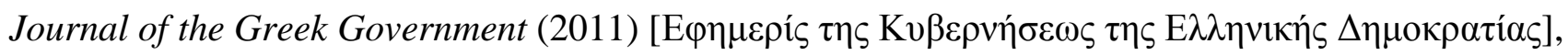
472(19780). Retrieved from http://edu.klimaka.gr/nomothesia/fek/1278-proypotheseisdiadikasies-adeia-leitourgias-ees-fek-472-2011.html

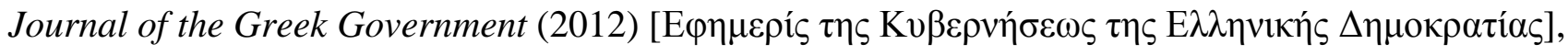
222(1), 5525-5648.

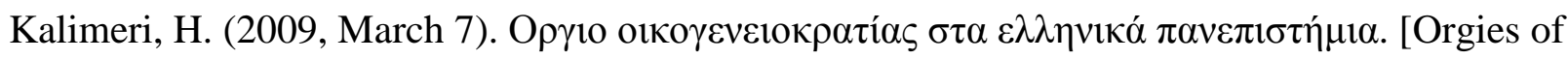

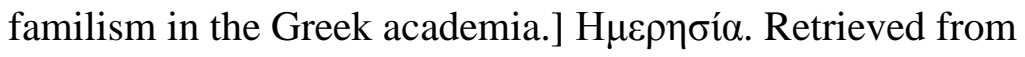
http://www.imerisia.gr/article.asp?catid=26510\&subid=2\&pubid=5993139\&tag=9360

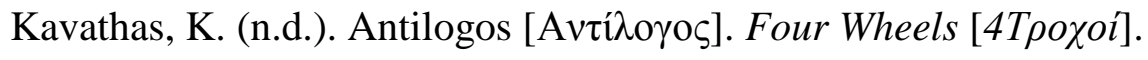


Kim, S. (2013). Networking enablers, constraints and dynamics: A Qualitative analysis. Career Development International, 18, 120-138.

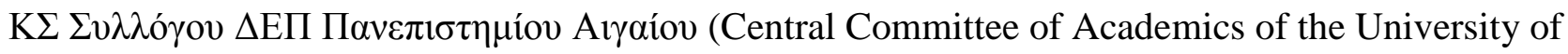

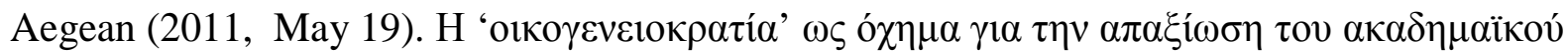
$\pi \rho о \sigma \omega \pi \iota \kappa o v ́$ [Web blog post]. Retrieved from http://politesna.blogspot.fr/2011/05/blogpost_19.html

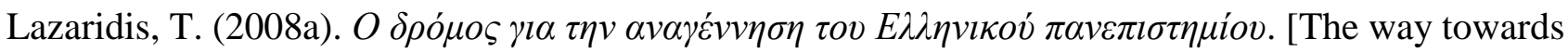

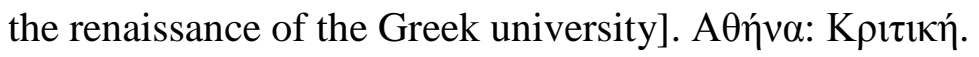

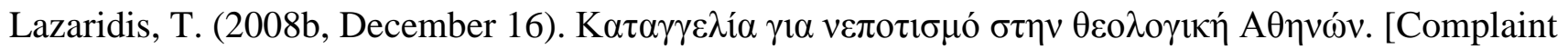
for nepotism in Theology Department of Athens University]. Greekuniversityreform.wordpress.com. Retrieved from http://greekuniversityreform.wordpress.com/2008/12/16/\%CE\%BA\%CE\%B1\%CF\%84\%CE\%B 1\%СE\%B3\%СE\%B3\%CE\%B5\%CE\%BB\%CE\%AF\%CE\%B1-\%CE\%B3\%CE\%B9\%CE\%B1-

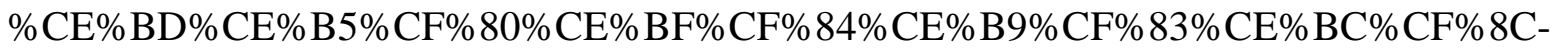
\%CF\%83\%CF\%84\%CE\%B7\%CE\%BD\%СЕ\%В8\%СЕ\%В5\%СЕ\%ВF\%СЕ\%ВB\%СЕ\%ВF\%СЕ\%В3/

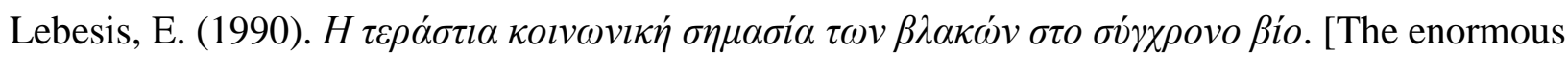

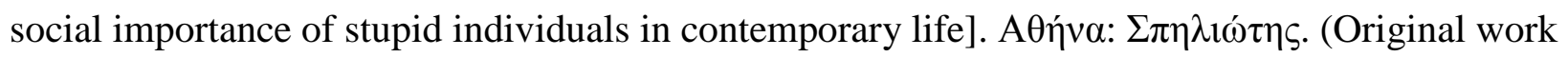
published 1941)

Lewis, M. (2010). The big short: Inside the doomsday machine. New York: W. W. Norton \& Company.

Lin, J., \& Si, S. X. (2010). Can guanxi be a problem? Contexts, ties, and some unfavorable consequences of social capital in China. Asia Pacific Journal of Management, 27, 561-581. Luthans, F., Youssef, C. M., \& Avolio, B. J. (2007). Psychological capital. New York: Oxford University Press. 
Malesevic, S. (2002). Ideology, legitimacy and the new state: Yugoslavia, Serbia and Croatia. London: Routledge.

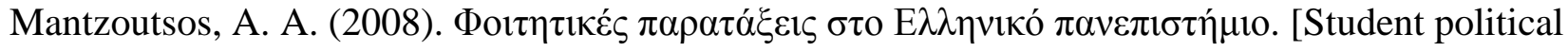

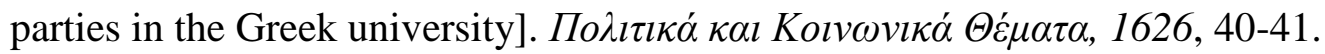

Mastrobuoni, G., \& Patacchini, E. (2012). Organized crime networks: An application of network analysis techniques to the American mafia. Review of Network Economics, 11(3), ISSN (Online) 1446-9022, DOI: 10.1515/1446-9022.1324

Mazar, N., \& Aggarwal, P. (2011). Greasing the palm: Can collectivism promote bribery? Psychological Science, 22, 843-848.

Middendorf, C. H., \& Macan, T. H. (2002). Note-taking in the employment interview: Effects on recall and judgements. Journal of Applied Psychology, 87, 293-303.

Miller, C. C., Cardinal, L. B., \& Glick, W. H. (1997). Retrospective reports in organizational research: A reexamination of recent evidence. Academy of Management Journal, 40, 189-204.

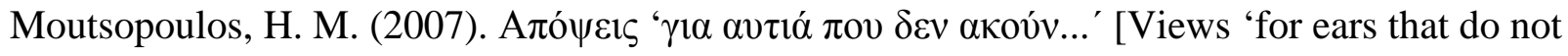

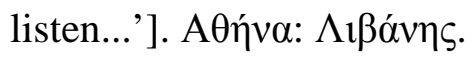

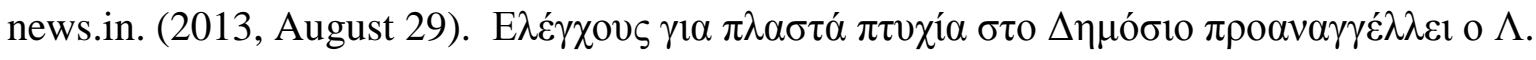

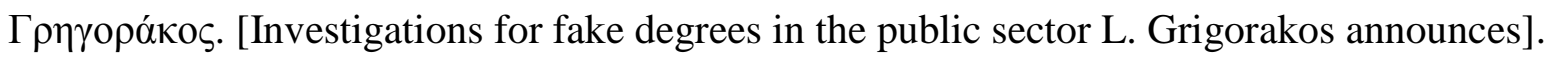
news.in.gr. Retrieved from http://news.in.gr/greece/article/?aid=1231262997

Norton \& Company (2010). The civilization of Greece, 1000-400 B.C.E. In Norton \& Company (Ed.), Western civilizations. Retrieved from http://www.wwnorton.com/college/history/westerncivilization17/

Numerato, D., \& Baglioni, S. (2012). The dark side of social capital: Ethnography of sport governance. International Review for the Sociology of Sport, 47, 594-611.

OECD (2012). Human resources management country profiles: Greece. Paris: OECD Publishing. 


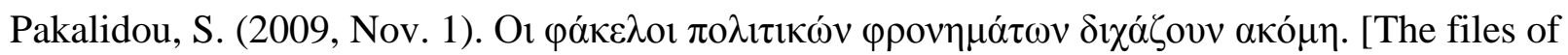

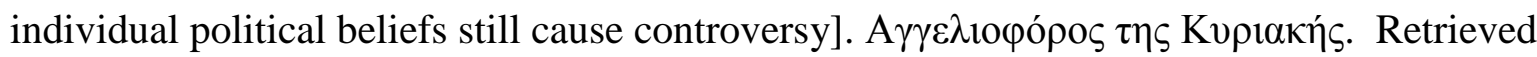
from http://www.agelioforos.gr/default.asp?pid=7\&ct=10\&artid=9240

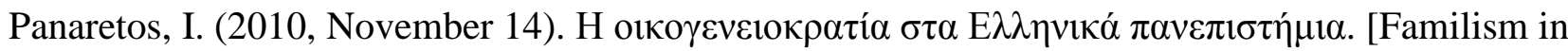
the Greek universities]. [Web blog post]. Retrieved from http://panaretos.blogspot.fr/2010/11/blog-post_14.html

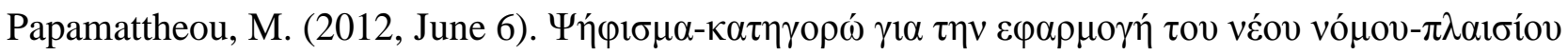

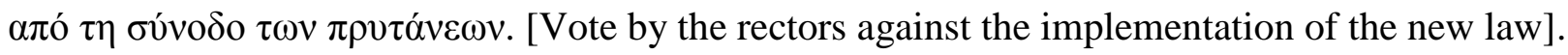
To Bиं $\mu \alpha$. Retrieved from http://www.tovima.gr/education/article/?aid=464824

Parker, P., Khapova, S. N., \& Arthur, M. B. (2009). The intelligent career framework as a basis of interdisciplinary inquiry. Journal of Vocational Behavior, 75, 291-302.

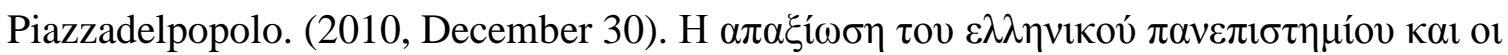

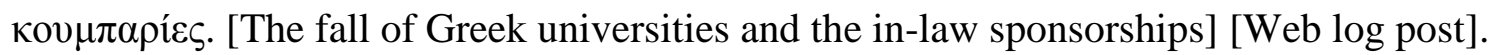
Retrieved from http://piazzadelpopolo.blogspot.fr/2010/12/blog-post_3689.html

Porter, S., Spencer, L., \& Birt, A. R. (2003). Blinded by emotion? Effect of the emotionality of a scene on susceptibility of false memories. Canadian Journal of Behavioural Science, 35, 165175.

Portes, A. (1998). Social capital: Its origins and applications in modern sociology. Annual Review of Sociology, 24, 1-24.

Prusak, L., \& Cohen, D. (2001). How to invest in social capital. Harvard Business Review, 79(6), 8693.

Putman, R. D. (2000). Bowling alone: The collapse and revival of American community. New York: Simon \& Schuster.

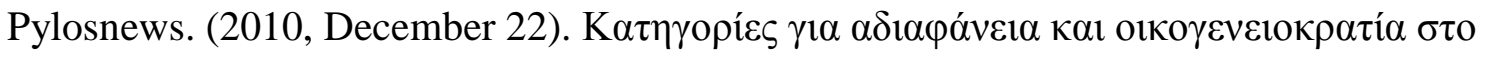
$\pi \alpha v \varepsilon \pi \imath \sigma \tau \eta \dot{\mu 10}$ [Accusations for lack of transparency and nepotism in the university] [Web log post]. Retrieved from http://pylosnews.blogspot.fr/2010/12/blog-post_22.html 
Quinn, J. (2012, September 29). Stephen Hester: Banking culture change 'will take a generation'. The Telegraph. Retrieved from http://www.telegraph.co.uk/finance/newsbysector/banksandfinance/9576646/Stephen-HesterBanking-culture-change-will-take-a-generation.html

Realo, A., Allik, J., \& Greenfield, B. (2008). Radius of trust: Social capital in relation to familism and institutional collectivism. Journal of Cross-Cultural Psychology, 39, 449-462.

Sakwa, R. (1999). The rise and fall of the Soviet Union, 1917-1991. London: Routledge.

Seibert, S. E., Kraimer, M. L., \& Liden, R. C. (2001). A social capital theory of career success. Academy of Management Journal, 44, 219-237.

Soot, M-L., \& Rootalu, K. (2012). Institutional trust and opinions of corruption. Public Administration and Development, 32, 82-95.

Super, D. E. (1957). The psychology of careers. New York: Harper \& Row.

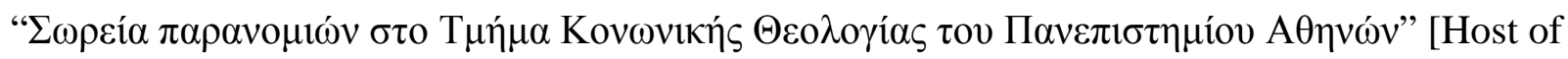
illegal activities in the Department of Social Theology of Athens University]. (2010, November 20). Retrieved from http://news.in.gr/greece/article/?aid=1231068243

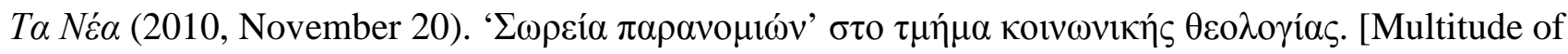
illegal activities in the department of social theology]. Retrieved from http://www.tanea.gr/ellada/article/?aid=4605329

Teagarden, M. B., \& Schotter, A. (2013). Favor prevalence in emerging markets: A multi-level analysis. Asia Pacific Journal of Management, 30, 447-460.

Testa, J. (2012). The Thomson Reuters journal selection process. Philadelphia, PA: Thomson Reuters.

Transparency International (2012). Corruption Perceptions Index. Retrieved from http://cpi.transparency.org/cpi2012/results/\#myAnchor1

Triandis, H. C., Vassiliou, V., \& Nassiakou, M. (1968). Three cross-cultural studies of subjective culture. Journal of Personality and Social Psychology Monograph Supplement, 8(4), 1-42. 


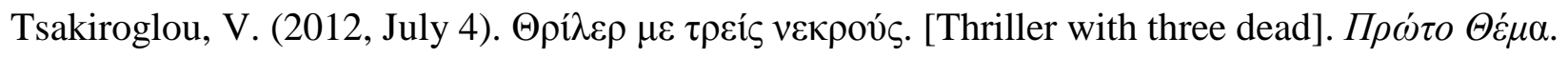
Retrieved from http://www.protothema.gr/Stories/article/208480/thriler-me-treis-nekroys/

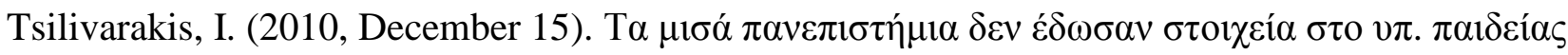

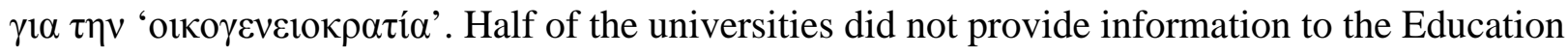
ministry regarding 'familism']. [Web log post]. Retrieved from http://blogs.sch.gr/tsilivar/2010/12/15/\%CF\%84\%CE\%B1$\% \mathrm{CE} \% \mathrm{BC} \% \mathrm{CE} \% \mathrm{~B} 9 \% \mathrm{CF} \% 83 \% \mathrm{CE} \% \mathrm{AC}-$ \%СF\%80\%СЕ\%В1\%СЕ\%BD\%СЕ\%В5\%СF\%80\%СЕ\%В9\%СF\%83\%СF\%84\%СЕ\%АE\%СЕ $\% \mathrm{BC} \% \mathrm{CE} \% \mathrm{~B} 9 \% \mathrm{CE} \% \mathrm{~B} 1-\% \mathrm{CE} \% \mathrm{~B} 4 \% \mathrm{CE} \% \mathrm{~B} 5 \% \mathrm{CE} \% \mathrm{BD}-$ $\% \mathrm{CE} \% \mathrm{AD} \% \mathrm{CE} \% \mathrm{~B} 4 \% \mathrm{CF} \% 89 \% \mathrm{CF} \% 83 \% \mathrm{CE} \% \mathrm{~B} 1 \% \mathrm{CE} \% \mathrm{BD}-$ \%СF\%83\%СF\%84\%СЕ\%BF\%СE\%B9\%СF\%87/

United Nations (2013). Member States. United Nations. Retrieved from http://www.un.org/en/members/

Van Deth, J. W., \& Zmerli, S. (2010). Introduction: Civicness, equality, and democracy - a “dark side” of social capital? American Behavioral Scientist, 53, 631-639.

Waldman, D. A., de Luque, M. S., Washburn, N., House, R. J., Adetoun, B., Barrasa, A. ... \& Wilderom, C. (2006). Cultural and leadership predictors of corporate social responsibility values of top management: A GLOBE study of 15 countries. Journal of International Business Studies, $37,823-837$.

Wang, D., Wang, L., Fan, X., \& Gao, W. (2013). Impact of psychological capital on job burnout and job engagement of knowledge workers. Chinese Journal of Behavioral Medicine and Brain Science, 22, 354-356.

Watson, M., \& McMahon, M. (2005). Children's career development: A research review from a learning perspective. Journal of Vocational Behavior, 67, 119-132.

Wilkinson, J. D., \& Hughes, H. S. (2003). Contemporary Europe: A history (10 ${ }^{\text {th }}$ ed.). New York: Pearson. 


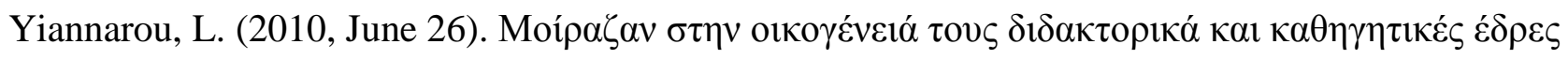

[They were awarding doctorates and academic positions to members of their own family]. $H$ $K \alpha \theta \eta \mu \varepsilon \rho v \eta \dot{.}$ Retrieved from

http://news.kathimerini.gr/4dcgi/_w_articles_ell_1_23/06/2010_405505

“45 journals used in FT research rank" (2012, Feb. 22). The Financial Times. Retrieved from http://www.ft.com/cms/s/2/3405a512-5cbb-11e1-8f1f-00144feabdc0.html\#axzz2SimUDWp2

\section{Footnotes}

${ }^{1}$ This is to some extent a paradox. That is the public is aware of the corruption levels within Greek academia, but people in such positions are still respected (though admittedly this reverence has been gradually declining). A plausible explanation is the robustness of intellect and education as core cultural values since the time of ancient Greece, which have not been eroded yet by the changes of modern society that are relatively recent.

${ }^{2}$ Despite what might be the common belief outside Greece, academic salaries in Greece are not low and are in fact, especially before the recent austerity measures, comparable to those in more affluent European countries like, for example, France.

${ }^{3}$ To illustrate, the first, and only to date, time that academics saw cuts in their pay, in the vicinity of $10 \%$, was the end of 2012 (Journal of the Greek Government, 2012) while the, multiple, pay cuts for the rest of the public sector started at the beginning of 2010 and have totaled until present nearly $50 \%$ decrease in annual earnings.

${ }^{4}$ New legislation voted by the parliament in September 2011 includes the element of trustees in universities and limits the formal involvement of political parties. However, this new structure has been met with fierce resistance, including resistance from the rectors themselves (Papamattheou, 2012), and has yet to be implemented (Edopanepistimio.uoa., 2013). At this point it is important to note that the previous legislative framework (2007) was never really implemented, a fact that poses serious doubts on whether they will be any substantive rather than nominal implementation of the 
new legislation. This should be also seen within the context of the whole Greek public sector, where there is a very wide gap between legislation or what is supposed to happen "on paper" and what happens in reality (Bozionelos, 2011). In addition, considering how the Greek academia currently operates, even if those structures are eventually implemented it is highly doubtful that any external control bodies will be impartial and will play the role they are supposed to play or will in fact be simply affiliates or members of the "in-group".

${ }^{5}$ See Footnote 4.

${ }^{6}$ Another major case of corruption that had been surfaced by the media back in the 1990s involved a widespread operation of illegally transferring the offspring of academics and politicians from universities abroad into Greek universities. Greek universities have limited numbers of places for undergraduate study, hence, they require highly competitive entry exams (which are administered exclusively by the Ministry of Education, and they consist in essence the only impartial institution in Greece). Academics with the assistance of insiders in the Ministry of Education had been saving their offspring and the offspring of many politicians (plus those of anyone else who was able to pay the hefty fee involved) from the uncertainty and harshness of the university entrance system in the following way: first, having them registered in foreign universities and then subsequently transferring them illegally into their preferred faculties of Greek universities. The scale and time length of the operation had been enormous. However, and despite that a number of attorney generals were involved, the case was eventually hushed up and "archived" (Edu_gr, 2011b). This further demonstrates the untoutchability of the "in-group", and justifies the argument that the "in-group" may in fact own the whole Higher Education system in Greece and not only its labour market.

${ }^{7}$ Indeed, in the only case ever that individuals who were in the upper ranks of a Higher Education institution have been held accountable the whistle was essentially blown by people outside academia (they were the aged widows of ex-deputy rectors) while the evidence was unshakable - it may be interesting for the reader to know that the case took nearly a decade to conclude, and in the process key individuals with incriminating knowledge sustained organized life-threatening physical 
attacks while university archives that contained the incriminating evidence were arsonned (...) (Tsakiroglou, 2012). The direct relevance of that case to our subject (i.e., careers within the Greek academia) is that the career trajectory of the pivotal academic implicated is typical of career patterns that "in group" members enjoy: offspring of a wealthy and influential family with strong political connections, failed the entry exams into the Greek University, was sent abroad to acquire credentials, was given an academic position in the Greek academia immediately upon completion of his studies, and nearly instantaneously ascended (or better "jumped") all academic ranks to become rector with the backing of three major political parties in the process... In addition, the case is illustrative of the profound sense of untouchability and unaccountability "in group" members possess (as reflected, for example, in directly using the university budget to purchase, amongst others, private Ferraris...).

${ }^{8}$ Another major deterrent against going abroad for people who have already spent a substantial number of years in Greek academia is that leaving with less than 25 years of service in essence removes pension rights. Unlike most other countries where all pension contributions count, in Greece there is no pension entitlement if one resigns with less than 25 years of service.

${ }^{9}$ Allegations for possession of fake doctoral or undergraduate degrees by "in group" members abound (e.g., T $\alpha$ Né $\alpha, 2010)$. The author did happen to hear about such cases, but he did not personally encounter those individuals whom the allegations/rumours concerned - though he had encountered some of the Professoriate members who allegedly backed these cases. And he prefers to be reserved on that matter. Nevertheless, given that the only people who may actually "see" the academic degrees as physical documents are members of the Professoriate and certain officials in the ministry, the scenario for occasional use of fake qualifications by the "in group" does not appear so unlikely. Recent revelations by the government itself that more than $10 \%$ of those in the civil service (of which academia is part) have been hired with fake degrees (news.in, 2013) adds some further plausibility to that scenario.

${ }^{10}$ The doctoral degree system is Greece has even fewer controls and accountabilities than the academic labour market. It is not uncommon for doctorates to take twice as long to complete than in 
other European countries (for "outsiders" that is) or for the candidate to eventually give up. Reasons include lack of attention by the advisory committee and, especially, forced involvement in other activities, such as teaching and secretarial tasks. Doctoral students who are "outsiders" are typically utilized by staff members as unpaid teaching assistants, who do most or all teaching and marking that is supposedly performed by staff members, and as secretaries. If the candidate has no links to the Professoriate or to political parties he/she has absolutely no protection (needless to note that there is no "grievance system", but even if such a system existed "on paper" it would be only nominal). And in some cases doctoral students are asked to leave once they complete their fieldwork, which is then utilized by "in-group" doctoral students or staff members for their own benefit.

${ }^{11}$ It should be noted here that the Deputy Minister of Case \#2 had also asked universities to provide lists with names of all teaching fellows, what courses they teach, whose teaching they cover, and the reason for that. Having himself insider experience as academic within the Greek system he was very aware of that phenomena and their scope.

${ }^{12}$ It is worth stressing for the reader that reaching tenure by no means does it mean reaching "safety" for an "outsider". Though it does come with substantial relief, tenure does not fully immunize against the "in group". As noted, the legislation is labyrinthine with many footnotes and special regulations. Hence, someone can still face dismissal or other serious consequences for relatively trivial matters (that in many cases can also be "concocted"). This does happen when tenured (or untetured) "outsiders" are seen by the Professoriate as imposing real danger.

${ }^{13}$ As in Footnote 11

${ }^{14}$ As in Footnote 11

${ }^{15}$ The new law on Higher Education, that has yet to be implemented, includes evaluation of the research output of universities. If the law is eventually implemented in substance and not "on paper" only the most likely logical outcome will be intensification of this phenomenon.

${ }^{16}$ As in footnote 15. 
${ }^{17}$ When the author himself applied for his academic position in the Greek Higher Education sector he had to hire special cargo to post the 40+ kilos that the application material weighted.

${ }^{18}$ Another common characteristic of male "in group" members is either full exemption from military service, which is compulsory in Greece, or a seriously abridged or nominal service. How this is achieved must by now be evident to the reader.

${ }^{19}$ The Greek adjective is " $\gamma \rho \alpha \varphi \imath \kappa o ́ \varsigma$ " and does not have direct translation in English. It indicates someone who is quixotically comical because of his/her persistence to publicly reiterate the same points on the same lost cause. 